\title{
Spectroscopic and chemical characterization of active and inactive Cu species in NO decomposition catalysts based on Cu-ZSM5
}

\author{
Patrick Da Costa, $\dagger^{a}$ Björn Modén, ${ }^{a}$ George D. Meitzner, ${ }^{b}$ Deuk Ki Lee $\ddagger^{a}$ and Enrique Iglesia*a \\ a Department of Chemical Engineering, University of California at Berkeley, Berkeley CA 94720, \\ USA. E-mail: iglesia@cchem.berkeley.edu \\ ${ }^{b}$ Edge Analytical, Inc., El Paso TX 79912, USA
}

Received 16th April 2002, Accepted 26th June 2002
First published as an Advance Article on the web 8th August 2002

The number and type of $\mathrm{Cu}^{2+}$ species present on $\mathrm{O}_{2}$-treated $\mathrm{Cu}-\mathrm{ZSM} 5$ catalysts $(\mathrm{Si} / \mathrm{Al}=13.1-14.6)$ with varying $\mathrm{Cu} / \mathrm{Al}$ ratios $(0.12-0.60)$ were measured using temperature-programmed reduction in $\mathrm{H}_{2}$ or $\mathrm{CO}$ and desorption of $\mathrm{O}_{2}$ with $\mathrm{He}$ as the carrier. The effluent stream was monitored using mass spectrometry and the structure and oxidation state was determined in parallel by X-ray absorption spectroscopy. Isolated $\mathrm{Cu}^{2+}$ monomers and oxygen-bridged $\mathrm{Cu}^{2+}$ dimers interacting with $\mathrm{Al}-\mathrm{Al}$ next nearest neighbor pairs were the predominant $\mathrm{Cu}$ species on these catalysts. The fraction of $\mathrm{Cu}$ present as dimers increased from 0.46 to 0.78 as $\mathrm{Cu} / \mathrm{Al}$ ratios increased from 0.12 to 0.60 , as expected from the decreasing average $\mathrm{Cu}-\mathrm{Cu}$ distance with increasing $\mathrm{Cu}$ content. In contrast, monomers reached a plateau of $\sim 0.15 \mathrm{Cu}^{2+} / \mathrm{Al}$, suggesting that only some $\mathrm{Al}-\mathrm{Al}$ pairs can interact with small $\mathrm{Cu}^{2+}$ monomer structures, while a much larger fraction can bind with larger oxygen-bridged $\mathrm{Cu}^{2+}$ dimers. The measured distribution of $\mathrm{Cu}$ dimers and monomers is consistent with the number and bond distances of $\mathrm{Al}-\mathrm{Al}$ pairs for the $\mathrm{Si} / \mathrm{Al}$ ratio in these ZSM5 samples. The distributions of $\mathrm{Cu}$ species obtained from the amount of $\mathrm{CO}_{2}$ formed (from $\mathrm{CO}$ ), the amount of $\mathrm{H}_{2} \mathrm{O}$ formed (from $\mathrm{H}_{2}$ ), and the amount of $\mathrm{CO}$ adsorbed after reduction in $\mathrm{CO}$ are in excellent agreement. The number of oxygen atoms removed as $\mathrm{O}_{2}$ was significantly smaller than that removed with $\mathrm{H}_{2}$ or $\mathrm{CO}$, suggesting that only proximate $\mathrm{Cu}$ dimers autoreduce via recombinative desorption steps. NO decomposition turnover rates (normalized per $\mathrm{Cu}$ dimer) were nearly independent of $\mathrm{Cu}$ content, except at the lowest $\mathrm{Cu} / \mathrm{Al}$ ratio, consistent with the involvement of $\mathrm{Cu}$ dimers as the active $\mathrm{Cu}$ species in NO decomposition redox cycles on Cu-ZSM5. Multiple $\mathrm{O}_{2}$ and $\mathrm{CO}_{2}$ peaks during desorption and reduction in $\mathrm{CO}$ suggest the presence of $\mathrm{Cu}$ dimers with varying oxygen binding energy and reactivity. The $\mathrm{Cu}$ dimers initially formed at low $\mathrm{Cu} / \mathrm{Al}$ contents during exchange are less reducible, consistent with their lower NO decomposition turnover rates.

\section{Introduction}

Direct decomposition of $\mathrm{NO}$ to $\mathrm{N}_{2}$ and $\mathrm{O}_{2}$ remains the most robust strategy for $\mathrm{NO}_{x}$ removal from combustion streams, because it does not require a co-reactant. NO decomposition is thermodynamically favored and $\mathrm{Cu}-\mathrm{ZSM} 5^{1}$ and supported noble metals ${ }^{2,3}$ catalyze this reaction, albeit at impractically low rates. NO decomposition pathways and the sites required for this reaction are relatively well understood for noble metal catalysts. Many studies of the active structures and NO decomposition pathways have been conducted on $\mathrm{Cu}$-ZSM5 and other cation-exchanged zeolites. The number and catalytic role of the various exchanged $\mathrm{Cu}$ cations and $\mathrm{CuO}$ species and the details of $\mathrm{N}-\mathrm{N}$ and $\mathrm{O}-\mathrm{O}$ bond formation during $\mathrm{NO}$ decomposition, however, remain subjects of active debate.

The exchange of $\mathrm{Cu}$ ions onto ZSM5 using aqueous $\mathrm{Cu}$ salts leads to $\mathrm{Cu}^{2+}$ species. Some of these species autoreduce to $\mathrm{Cu}^{+}$ during thermal treatment in $\mathrm{He}$ with the concurrent desorption of extraframework oxygen atoms as $\mathrm{O}_{2} \cdot{ }^{4-7}$ The expected presence of such species, together with electron spin resonance and thermogravimetric studies, ${ }^{7}$ suggest that redox cycles are

$\dagger$ Current address: Laboratoire Reactivite de surface, UMR CNRS 7609, Tour 54-55 case 178, Universite Pierre et Marie Curie, 4, place Jussieu, 75252 Paris Cedex 05, France.

$\ddagger$ Current address: Division of Civil and Environmental Engineering, Kwangju University, Kwangju, 503-703 Korea. responsible for NO decomposition turnovers. Infrared spectra of adsorbed $\mathrm{CO}$ and $\mathrm{NO}$ provided indirect evidence for the reversible cycling between $\mathrm{Cu}^{2+}$ and $\mathrm{Cu}^{+}$during switching between $\mathrm{O}_{2}$ and $\mathrm{He}$ streams at $773 \mathrm{~K}^{8}{ }^{8}$ These cycles were confirmed by X-ray photoelectron (XPS) and X-ray absorption (XAS) spectroscopic studies. ${ }^{9}$ The parallel increase in the concentration of $\mathrm{Cu}^{+}$species detected by XAS and in the rate of NO decomposition was used as evidence for $\mathrm{Cu}^{+}$as a reaction intermediate. ${ }^{10,11}$ A mechanism involving NO coordination to $\mathrm{Cu}^{2+}$ without the involvement of reduction-oxidation cycles has also been suggested ${ }^{12}$ but it has not been supported by experimental evidence. $\mathrm{N}-\mathrm{N}$ formation has been proposed to occur via adsorption of two $\mathrm{NO}$ molecules on a single $\mathrm{Cu}^{+}$site to form dinitrosyl complexes $\left\{\mathrm{Cu}^{+}(\mathrm{NO})_{2}\right\}$, which decompose to $\mathrm{N}_{2} \mathrm{O}$ and $\mathrm{Cu}^{2+} \mathrm{O}^{-} .6,13,14$ The awkward charge balance associated with $\mathrm{Cu}^{2+} \mathrm{O}^{-}$species ${ }^{15-17}$ can be avoided by placing each of the two NO molecules in the two vicinal $\mathrm{Cu}^{+}$cations within a $\left\{\mathrm{Cu}^{+}-\square-\mathrm{Cu}^{+}\right\}$pair ( $\square$; oxygen vacancy), which would then form $\mathrm{N}_{2} \mathrm{O}$ and an oxygen-bridged copper dimer $\left\{\mathrm{Cu}^{2+}-\mathrm{O}^{2-}-\mathrm{Cu}^{2+}\right\}^{2+} ., 18-20$ This step resolves the charge balance concerns and it is consistent with the observed increase in $\mathrm{NO}$ decomposition turnover rates as the $\mathrm{Cu} / \mathrm{Al}$ ratio increases and oxygen-bridged dimers become more prevalent. $^{21}$

Oxidized $\mathrm{Cu}$ dimers $\left\{\mathrm{Cu}^{2+}-\mathrm{O}^{2-}-\mathrm{Cu}^{2+}\right\}^{2+}$ and their reduced forms $\left\{\mathrm{Cu}^{+}-\square-\mathrm{Cu}^{+}\right\}^{2+}$ are not the only $\mathrm{Cu}$ species that can co-exist in $\mathrm{Cu}-\mathrm{ZSM} 5$, as shown by temperature-programmed 
reduction studies using $\mathrm{H}_{2}$ or $\mathrm{CO}$ as reductants. ${ }^{18,20}$ These studies have detected $\mathrm{CuO}$, isolated $\mathrm{Cu}^{2+}$, as well as $\mathrm{Cu}$ dimers $\left\{\mathrm{Cu}^{2+}-\mathrm{O}^{2-}-\mathrm{Cu}^{2+}\right\}^{2+}$. A quantitative assessment of the $\mathrm{Cu}^{2+} / \mathrm{Cu}^{+}$speciation during catalyst synthesis, thermal treatment, and catalytic NO decomposition has remained elusive, because of the dispersed nature of these structures, the nonuniform nature of the samples, and the dearth of available techniques to assess their structural features at realistic conditions. Yet, such site speciation remains the essential requirement to establish conclusively the redox nature and the site requirements of NO decomposition pathways. This challenge can be addressed most effectively by applying complementary spectroscopic and chemical techniques able to measure concentrations for each $\mathrm{Cu}$ species, so that their respective abundances can be related to the rate of the catalytic reaction of interest, in this case NO decomposition.

Elsewhere, we have reported transient and steady-state kinetic studies that provide mechanistic evidence for the involvement of $\mathrm{Cu}^{2+}$ dimers with one bridging extraframework oxygen atom as the prevalent state of the active $\mathrm{Cu}$ sites involved in $\mathrm{NO}$ decomposition and in $\mathrm{O}-\mathrm{O}$ bond formation. ${ }^{22,23}$ Here, we report chemical and spectroscopic characterization data for a series of $\mathrm{Cu}-Z \mathrm{SM} 5$ samples with varying $\mathrm{Cu} / \mathrm{Al}$ ratio using X-ray absorption spectra during oxygen removal by treatment with $\mathrm{H}_{2}, \mathrm{CO}$, or $\mathrm{He}$, along with mass spectrometric analysis of the amount of oxygen removed during these thermal treatments (as $\mathrm{H}_{2} \mathrm{O}, \mathrm{CO}_{2}$, or $\mathrm{O}_{2}$ ). These combined methods have led to a quantitative assessment of the number of $\mathrm{Cu}^{2+}$ and $\left\{\mathrm{Cu}^{2+}-\mathrm{O}^{2-}-\mathrm{Cu}^{2+}\right\}^{2+}$ species for samples with a wide range of $\mathrm{Cu} / \mathrm{Al}$ ratios and to the definite correlation of catalytic NO decomposition rates with the number of $\mathrm{Cu}$ dimers present in each sample.

\section{Experimental methods}

\section{Catalyst synthesis}

$\mathrm{Cu}$-ZSM5 catalysts were prepared with different $\mathrm{Cu} / \mathrm{Al}$ ratios by ion exchange using an aqueous solution of $\mathrm{Cu}\left(\mathrm{CH}_{3} \mathrm{COO}\right)_{2} \cdot \mathrm{H}_{2} \mathrm{O}$ (Sigma Aldrich, ACS reagent) and Na-ZSM5 (Zeochem; two batches, $\mathrm{Si} / \mathrm{Al}=13.2,14.5$ ). The molarity of this solution $\left(100 \mathrm{~cm}^{3} / \mathrm{g}\right.$-ZSM5 $)$ was varied between 0.01 and $0.1 \mathrm{M} \mathrm{Cu}\left(\mathrm{CH}_{3} \mathrm{COO}\right)_{2} \cdot \mathrm{H}_{2} \mathrm{O}$ in order to obtain $\mathrm{Cu} / \mathrm{Al}$ ratios between 0.12 and 0.60 . The $\mathrm{pH}$ of the solution was 5.5-6.0 during exchange. The exchange was carried out at ambient temperature for $20 \mathrm{~h}$ and the samples were then rinsed six times with doubly de-ionized water $\left(30 \mathrm{~cm}^{3}(\mathrm{~g} \mathrm{ZSM} 5)^{-1}\right.$ each time) with an intervening filtering step between each rinse. These rinse cycles were carried out in order to ensure that intraparticle liquids did not contain $\mathrm{Cu}$ cations, which would form crystalline $\mathrm{CuO}$ species during drying and thermal treatment. For some of the samples, this exchange procedure was repeated two or three times in an attempt to increase the $\mathrm{Cu} / \mathrm{Al}$ ratio. Samples were then dried in static ambient air at $383 \mathrm{~K}$ for $24 \mathrm{~h}$ and pelleted and sieved in order to retain agglomerates with $125-250 \mu \mathrm{m}$ diameter. The $\mathrm{Si}, \mathrm{Al}, \mathrm{Na}$ and $\mathrm{Cu}$ contents were measured by ion-coupled plasma emission spectroscopy or atomic absorption (Galbraith Laboratories) and reported in Table 1. We refer to samples as $\mathrm{Cu}(x)$, where $x$ is the atomic $\mathrm{Cu} / \mathrm{Al}$ ratio for each sample.

\section{Kinetics of oxygen removal and $\mathrm{Cu}$ reduction in $\mathrm{H}_{2}$, $\mathrm{CO}$ and $\mathrm{He}$}

The consumption of $\mathrm{H}_{2}$ and the formation of $\mathrm{H}_{2} \mathrm{O}$ were monitored as a function of temperature during reduction in $\mathrm{H}_{2}$ $\left(\mathrm{H}_{2}\right.$-TPR). The formation of $\mathrm{CO}_{2}$ during reduction in $\mathrm{CO}$ (CO-TPR) and the desorption of $\mathrm{O}_{2}$ during temperature ramping using $\mathrm{He}$ as the carrier gas (TPD) were also measured on
Table 1 Catalyst composition. $\mathrm{Cu}(0.38)$ and $\mathrm{Cu}(0.58)$ are from one ZSM5 batch, and $\mathrm{Cu}(0.12), \mathrm{Cu}(0.36)$ and $\mathrm{Cu}(0.60)$ are from another batch

\begin{tabular}{lccccc}
\hline Catalyst & $\mathrm{Cu}(0.12)^{a}$ & $\mathrm{Cu}(0.36)$ & $\mathrm{Cu}(0.38)$ & $\mathrm{Cu}(0.58)$ & $\mathrm{Cu}(0.60)$ \\
\hline $\mathrm{Cu}($ wt.\%) & 0.76 & 2.25 & 2.24 & 3.31 & 3.88 \\
$\mathrm{Si}($ wt.\%) & 38.2 & 36.3 & 37.9 & 36.0 & 37.5 \\
$\mathrm{Al}($ wt.\%) & 2.76 & 2.66 & 2.50 & 2.42 & 2.73 \\
$\mathrm{Na}($ wt.\%) & 1.69 & 0.64 & 0.51 & $<0.08$ & $<0.11$ \\
$\mathrm{Si} / \mathrm{Al}$ & 13.3 & 13.1 & 14.6 & 14.3 & 13.2
\end{tabular}

a Molar ratio of $\mathrm{Cu}$ to total $\mathrm{Al}$.

all samples. Catalyst samples $(0.2-0.3 \mathrm{~g})$ were held within a quartz tube and the effluent was analyzed using mass spectrometry as the sample temperature was increased in flowing $\mathrm{H}_{2}$, $\mathrm{CO}$, or He. Mass signals for $\mathrm{H}_{2}(2 \mathrm{amu}), \mathrm{He}(4 \mathrm{amu}), \mathrm{H}_{2} \mathrm{O}(18$ $\mathrm{amu}), \mathrm{CO}(28 \mathrm{amu}), \mathrm{O}_{2}$ (32 amu), Ar (40 amu) and $\mathrm{CO}_{2}(44$ $\mathrm{amu})$ were monitored every $10 \mathrm{~s}$ using a mass spectrometer (MKS Instruments, Orion Compact Residual Gas Analyzer) equipped with a differentially pumped atmospheric sampling system. $\mathrm{CO}_{2}$ and $\mathrm{H}_{2} \mathrm{O}$ response factors were calculated by reducing known amounts of $\mathrm{CuO}$ to $\mathrm{Cu}$ in $\mathrm{CO}$ and $\mathrm{H}_{2}$, respectively, and measuring the amount of $\mathrm{CO}_{2}$ and $\mathrm{H}_{2} \mathrm{O}$ formed.

Samples were treated similarly before $\mathrm{H}_{2}$-TPR, CO-TPR and $\mathrm{O}_{2}$-TPD measurements. The samples were contacted with a flow of $50 \% \mathrm{O}_{2} / \mathrm{He}$ (Matheson) $\left(4.165 \mathrm{~cm}^{3} \mathrm{~s}^{-1} \mathrm{~g}^{-1}\right.$; denoted herein as $\mathrm{O}_{2}$ gas) as the sample temperature was increased from ambient to $773 \mathrm{~K}$ at $0.167 \mathrm{~K} \mathrm{~s}^{-1}$ and held at $773 \mathrm{~K}$ for $2 \mathrm{~h}$. The samples were then cooled to ambient temperature and the $\mathrm{O}_{2}$ gas was replaced with $\mathrm{He}\left(8.335 \mathrm{~cm}^{3} \mathrm{~s}^{-1} \mathrm{~g}^{-1}\right)$ in order to remove any physisorbed species. For $\mathrm{H}_{2}$-TPR, the quartz tube was then cooled down to $\sim 220 \mathrm{~K}$ using liquid nitrogen, and $\mathrm{He}$ was replaced with $5 \% \mathrm{H}_{2} / \mathrm{Ar}$ (Praxair) at $2.085 \mathrm{~cm}^{3} \mathrm{~s}^{-1} \mathrm{~g}^{-1}$. After the intensity at 2 amu reached a constant value, the sample temperature was increased to $923 \mathrm{~K}$ at $0.167 \mathrm{~K} \mathrm{~s}^{-1}$. For CO-TPR, He was replaced with $1 \% \mathrm{CO} / \mathrm{He}$ (Praxair) at $2.085 \mathrm{~cm}^{3} \mathrm{~s}^{-1} \mathrm{~g}^{-1}$ and the samples were heated to $700 \mathrm{~K}$ at $0.167 \mathrm{~K} \mathrm{~s}^{-1}$. A $\mathrm{H}_{2}$-TPR was also carried out after a CO-TPR by cooling the sample to ambient temperature, then replacing the $1 \% \mathrm{CO} / \mathrm{He}$ gas with $\mathrm{He}$ in order to remove weakly adsorbed $\mathrm{CO}$, and finally replacing $\mathrm{He}$ with $5 \% \mathrm{H}_{2} / \mathrm{Ar}$. Then, the $\mathrm{H}_{2}$-TPR procedure described above was repeated, but with a final temperature of $800 \mathrm{~K}$ instead of $923 \mathrm{~K}$. For $\mathrm{O}_{2}$ TPD, the He flow rate was decreased to $2.5 \mathrm{~cm}^{3} \mathrm{~s}^{-1} \mathrm{~g}^{-1}$ and the sample was heated to $1000 \mathrm{~K}$ at $0.167 \mathrm{~K} \mathrm{~s}^{-1}$. Throughout the manuscript, when $\mathrm{O} / \mathrm{Cu}$ ratios are reported, the $\mathrm{Cu}$ refers to the total number of $\mathrm{Cu}$ atoms in the sample. When $\mathrm{O} / \mathrm{Cu}_{\text {dimer }}$ is reported instead, it refers to the total number of $\mathrm{Cu}$ atoms present in dimers.

\section{In situ X-ray absorption spectroscopy (XAS) experiments}

X-ray absorption spectra were measured using beamline 4-1 at the Stanford Synchrotron Radiation Laboratory. The ring was operated at $30-100 \mathrm{~mA}$ and $3.0 \mathrm{GeV}$ during the experiments. A two-crystal $\mathrm{Si}(220)$ monochromator was detuned by $30 \%$ in order to minimize harmonics. Our beam definition slit had vertical and horizontal apertures of 0.2 and $15 \mathrm{~mm}$, respectively, which defined a maximum energy resolution of $1 \mathrm{eV}$ at the $\mathrm{Cu}$ $\mathrm{K}$ edge $(8979 \mathrm{eV})$. The intensities of the incident beam $\left(\mathrm{I}_{0}\right)$, of the beam after passing through the sample $\left(I_{1}\right)$, and of the beam after passing through a $7.5 \mu \mathrm{m} \mathrm{Cu}$ foil placed after the sample $\left(\mathrm{I}_{2}\right)$ were monitored using $\mathrm{N}_{2}$-filled ion chamber detectors. Dynamic spectra were acquired during transient measurements at $11.25 \mathrm{eV}$ increments from 8880 to $8970 \mathrm{eV}, 0.6 \mathrm{eV}$ increments from 8970 to $9005 \mathrm{eV}$, and $8 \mathrm{eV}$ increments from 9005 to $9223 \mathrm{eV}$. The absorption intensity data were integrated 
for $0.5 \mathrm{~s}$ at each energy for a total acquisition time of $144 \mathrm{~s}$ per transient spectrum.

Samples $(10 \mathrm{mg})$ were held within a quartz capillary $(0.8 \mathrm{~mm}$ inner diameter, $0.1 \mathrm{~mm}$ wall thickness), which acts as an isothermal tubular reactor with plug-flow hydrodynamics and walls transparent to X-rays. ${ }^{24,25}$ The samples were contacted with a flow of $50 \% \mathrm{O}_{2} / \mathrm{He}$ (Matheson) $\left(3.33 \mathrm{~cm}^{3} \mathrm{~s}^{-1} \mathrm{~g}^{-1}\right)$ as the temperature was increased from ambient to $773 \mathrm{~K}$ at $0.167 \mathrm{~K} \mathrm{~s}^{-1}$ and held at $773 \mathrm{~K}$ for $2 \mathrm{~h}$. The samples were then cooled to ambient temperature and the $\mathrm{O}_{2}$-containing stream was replaced by $\mathrm{He}\left(3.33 \mathrm{~cm}^{3} \mathrm{~s}^{-1} \mathrm{~g}^{-1}\right)$ in order to remove any physisorbed species, as described above. Finally, $\mathrm{H}_{2}$-TPR experiments were performed by replacing the $\mathrm{He}$ with $5 \% \mathrm{H}_{2} / \mathrm{Ar}$ (Praxair) at $3.33 \mathrm{~cm}^{3} \mathrm{~s}^{-1} \mathrm{~g}^{-1}$, and increasing the sample temperature to $800 \mathrm{~K}$ at $0.067 \mathrm{~K} \mathrm{~s}^{-1}$. The heating rate was kept at these low values in order to obtain essentially isothermal conditions during each XANES spectrum.

\section{X-Ray absorption near-edge (XANES) analysis}

Near-edge and fine structure data analyses were carried out using WinXAS version 2.1. ${ }^{26,27}$ The energy scale was calibrated by assigning the first inflection point in the $\mathrm{Cu}$ foil standard to an energy of $8979 \mathrm{eV}$. A linear regression fit to the pre-edge region between 8891 and $8952 \mathrm{eV}$ was subtracted from the spectrum, and the spectrum was normalized using a second-order polynomial fit of the post-edge region (9068$9223 \mathrm{eV})$. Principal component analyses (PCA) ${ }^{28}$ and linear combination $^{29}$ methods were used in order to measure the number, type, and concentration of each structurally distinct $\mathrm{Cu}$ species contributing to the $8900-9100 \mathrm{eV}$ energy region in each spectrum.

\section{Catalytic NO decomposition rate measurements}

Catalytic NO decomposition rates were measured using a compact multi-tube $(2.5 \mathrm{~mm}$ inner diameter) reactor designed to evaluate eight samples $(50 \mathrm{mg})$ simultaneously at a given temperature and feed composition and at individually controlled reactant flow rates. The reactors were tightly held within a cylindrical steel block inside a resistively heated furnace (Applied Test Systems, Series 3210, 1290 W). Thermocouples were placed within the steel block a short distance from each reactor near the middle of each catalyst bed. Catalyst samples were treated in $\mathrm{He}$ (UHP grade; $0.50 \mathrm{~cm}^{3} \mathrm{~s}^{-1}$ ) for $1 \mathrm{~h}$ at $823 \mathrm{~K}$ before introducing a reactant mixture containing $1.0 \% \mathrm{NO} /$ $9.98 \% \mathrm{Ar} / 89.02 \% \mathrm{He}$ and denoted here as $1 \% \mathrm{NO}$ gas (Matheson). The flow of the reactant mixture was kept at 1.0 $\mathrm{cm}^{3} \mathrm{~s}^{-1}$ through each reactor using fine metering valves. The effluent streams from each reactor were sequentially routed to the mass spectrometer for analysis using an eight-port switching valve (Valco Instruments, Multiposition valve STF). The species monitored by mass spectrometry were: He (4 amu), NO (30 amu), $\mathrm{N}_{2}(28 \mathrm{amu}), \mathrm{O}_{2}$ (32 amu), Ar (40 $\mathrm{amu}), \mathrm{N}_{2} \mathrm{O}(44 \mathrm{amu})$, and $\mathrm{NO}_{2}(46 \mathrm{amu})$. The mass spectrometer response was calibrated before and after each experiment using two certified gas mixtures containing $0.05 \% \mathrm{~N}_{2}$, $0.05 \% \mathrm{O}_{2}, 0.05 \% \mathrm{~N}_{2} \mathrm{O}, 10 \% \mathrm{Ar}$, and $89.85 \% \mathrm{He}$, and $0.05 \%$ $\mathrm{NO}_{2}, 9.94 \% \mathrm{Ar}$, and $90.01 \% \mathrm{He}$, both provided by Praxair.

\section{Results and discussion}

\section{Cu speciation in Cu-ZSM5 after exchange and thermal treatment}

Several types of $\mathrm{Cu}$ species can co-exist after synthesis and thermal treatment in air (Fig. 1). During synthesis via ionexchange, $\mathrm{Cu}^{2+}$ species in aqueous acetate solutions can replace $\mathrm{Na}^{+}$cations as solvated $\left\{\mathrm{Cu}^{2+}-(\mathrm{OH})^{-}\right\}^{+}$ions, ${ }^{30}$ which can then react with zeolitic $\mathrm{OH}$ groups or with another
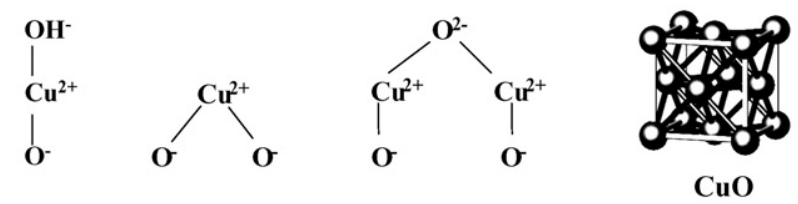

I

II

III

IV

Fig. 1 Divalent $\mathrm{Cu}$ species in $\mathrm{Cu}-\mathrm{ZSM}$ 5: (I and II): isolated copper species, (III): copper dimer species, (IV): bulk copper oxide.

$\left\{\mathrm{Cu}^{2+}-(\mathrm{OH})^{-}\right\}^{+}$ion during subsequent thermal treatment to form $\mathrm{Cu}^{2+}$ monomers or $\left\{\mathrm{Cu}^{2+}-\mathrm{O}^{2-}-\mathrm{Cu}^{2+}\right\}^{2+}$ dimers, respectively, each interacting with two charge-balancing framework Al sites in ZSM5. ${ }^{18,20} \mathrm{Cu}^{+}$ions are not likely to be stable in the $\mathrm{Cu}$ acetate solutions used for exchange, so exchanged $\mathrm{Cu}^{+}$species and $\mathrm{Cu}_{2} \mathrm{O}$ crystallites are not likely to form during synthesis or during subsequent treatment in oxidizing environments (except as a result of autoreduction at very high temperatures). $\left\{\mathrm{Cu}^{2+}-(\mathrm{OH})^{-}\right\}^{+}$ions can also precipitate as $\mathrm{Cu}(\mathrm{OH})_{2}$ crystallites but only at $\mathrm{pH}$ levels higher than those prevalent during ion exchange (above $\mathrm{pH} 6)^{31}$ or they can crystallize from solution during drying; neither of these possibilities is likely because of the slightly acidic $\mathrm{pH}$ of the acetate solutions and because any residual $\mathrm{Cu}^{2+}$ ions within the catalyst agglomerates are removed during the multiple rinsing cycles. Thus, the formation of $\mathrm{CuO}$ and $\mathrm{Cu}(\mathrm{OH})_{2}$ after exchange and thermal treatment is unlikely with our synthesis procedures. Indeed, three consecutive ion exchanges led to only a slight increase in $\mathrm{Cu} / \mathrm{Al}$ ratios from 0.57 to 0.60 and finally to 0.61 . This shows that the incorporation of $\mathrm{Cu}$ ions into the ZSM5 structure is limited by the number of exchange sites with sufficiently proximate Al framework cations that allow them to interact with one or two $\mathrm{Cu}^{2+}$ cations. If $\mathrm{Cu}$ species formed without association with zeolite (e.g., as $\mathrm{CuO}$ or $\left.\mathrm{Cu}(\mathrm{OH})_{2}\right)$, they would continue to form during sequential exchange cycles.

Monomeric $\mathrm{Cu}^{2+}$ species can exist as $\left\{\mathrm{Cu}^{2+}-(\mathrm{OH})^{-}\right\}^{+}(\mathrm{I})$ or as $\mathrm{Cu}^{2+}$ monomers (II) (Fig. 1). Species (I) has been detected only after low-temperature thermal treatments of exchanged samples, ${ }^{30,32,33}$ even though statistical isolation of some $\left\{\mathrm{Cu}^{2+}-(\mathrm{OH})^{-}\right\}^{+}$from other such species or from acidic $\mathrm{OH}$ would prevent their dehydration to form $\left\{\mathrm{Cu}^{2+}-\mathrm{O}^{2-}\right.$ $\left.\mathrm{Cu}^{2+}\right\}^{2+}$ or $\mathrm{Cu}^{2+}$ species, unless $\left\{\mathrm{Cu}^{2+}-(\mathrm{OH})^{-}\right\}^{+}$species and associated framework $\mathrm{Al}$ sites become mobile during thermal treatment. The probability of dimer formation increases with increasing $\mathrm{Cu} / \mathrm{Al}$ ratio; the presence of these dimers has been inferred from the removal of oxygen atoms from exchanged samples via autoreduction in $\mathrm{He}$ and via formation of $\mathrm{H}_{2} \mathrm{O}$ and $\mathrm{CO}_{2}$ during reduction with $\mathrm{H}_{2}$ and $\mathrm{CO}$ respectively. ${ }^{18,20}$ In the next section, we examine the reaction of $\mathrm{Cu}-\mathrm{ZSM} 5$ with $\mathrm{H}_{2}$ and the kinetics and stoichiometry of $\mathrm{Cu}^{2+}$ reduction and of $\mathrm{H}_{2} \mathrm{O}$ formation with increasing temperature.

\section{Reduction of $\mathrm{Cu}^{2+}$ species in $\mathrm{Cu}-\mathrm{ZSM5}$ using $\mathrm{H}_{2}$}

$\mathrm{H}_{2}$ consumption and $\mathrm{H}_{2} \mathrm{O}$ formation rates on $\mathrm{Cu}(0.12)$, $\mathrm{Cu}(0.36), \mathrm{Cu}(0.58)$, and $\mathrm{Cu}(0.60)$ samples are shown as a function of temperature in Fig. 2. Two $\mathrm{H}_{2}$ consumption peaks centered at $\sim 450 \mathrm{~K}$ and $\sim 650 \mathrm{~K}$ were detected in all samples. These data differ from some previously reported results, in which three distinct peaks were reported for Cu-ZSM5 samples with $\mathrm{Cu} / \mathrm{Al}$ ratios $(0.75)$ similar to some of the samples in Fig. $2{ }^{18}$ The third peak in these samples appeared near ambient temperatures and it was assigned to the reduction of $\mathrm{Cu}^{2+}$ dimers (Species III). ${ }^{18}$ In our experiments, the temperature ramp started at $\sim 220 \mathrm{~K}$ in order to ensure rigorous detection of any reduction processes occurring near ambient temperatures. In contrast with previous studies, we failed to detect 


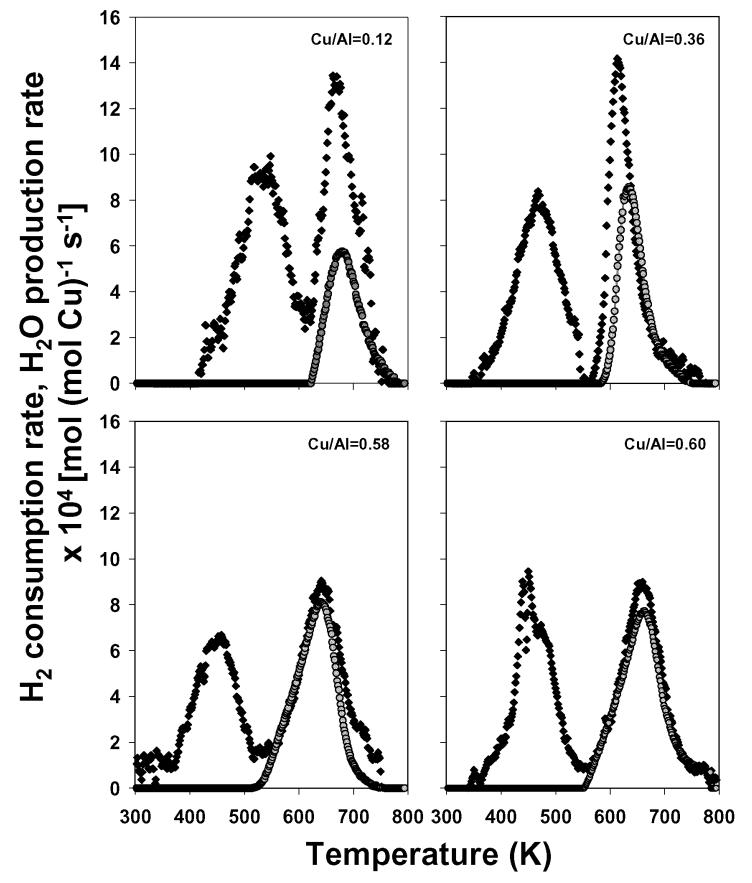

Fig. 2 Temperature programmed reduction in $5 \% \mathrm{H}_{2} / \mathrm{Ar}\left(0.417 \mathrm{~cm}^{3}\right.$ $\left.\mathrm{s}^{-1}\right)$ at $0.167 \mathrm{~K} \mathrm{~s}^{-1}$, for different $\mathrm{Cu} / \mathrm{Al}$ ratios $(0.2 \mathrm{~g})$, ( $\left.\diamond\right)$ hydrogen consumption rate, and (O) $\mathrm{H}_{2} \mathrm{O}$ production rate.

any $\mathrm{H}_{2}$ consumption or any $\mathrm{H}_{2} \mathrm{O}$ formation below $400 \mathrm{~K}$. We did detect an initial decrease in the $\mathrm{H}_{2}$ gas phase concentration upon switching from $\mathrm{He}$ to the $\mathrm{H}_{2}$ mixture, irrespective of the temperature at which the switch occurs; this peak was observed even on Na-ZSM5 and H-ZSM5. It arises from the replacement of He held within zeolite channels with the $\mathrm{H}_{2-}$ containing mixture, which leads to the net removal of some $\mathrm{H}_{2}$ from the reactant gas stream. The evolution of $\mathrm{H}_{2} \mathrm{O}$ coincided with the $\mathrm{H}_{2}$ consumption peak at $\sim 650 \mathrm{~K}$ (Fig. 2).

Before proceeding with the assignment of these two peaks to specific reduction processes and $\mathrm{Cu}^{2+}$ species, we consider first the amount of $\mathrm{H}_{2}$ consumed $\left(\mathrm{H}_{2} / \mathrm{Cu}\right)$ and the amount of $\mathrm{H}_{2} \mathrm{O}$ formed $\left(\mathrm{H}_{2} \mathrm{O} / \mathrm{Cu}\right)$ indicated by the data in Fig. 2 and shown in Table 2. At all $\mathrm{Cu} / \mathrm{Al}$ ratios (in the $0.12-0.60$ range), the total $\mathrm{H}_{2} / \mathrm{Cu}$ ratio was $0.97-1.01$, indicating that all the $\mathrm{Cu}^{2+}$ ions have undergone a two-electron reduction to $\mathrm{Cu}^{0}$ by the final treatment temperature $(773 \mathrm{~K})$. The total amount of $\mathrm{H}_{2}$ consumed is equally distributed between the two reduction peaks, each one of which corresponds to $\sim 0.5 \mathrm{H}_{2} / \mathrm{Cu}$ (Fig. 2). This suggests that all $\mathrm{Cu}$ starts in oxidation state $2+$, reduces fully to $\mathrm{Cu}^{+}$during the first reduction peak and to $\mathrm{Cu}^{0}$ during the second reduction peak. This result also confirms that the $\mathrm{O}_{2}$ treatment used for all samples before reduction leads to the stoichiometric formation of $\mathrm{Cu}^{2+}$ without any detectable autoreduction. The amount of $\mathrm{H}_{2} \mathrm{O}$ evolved ranges from 0.26 to

Table $2 \mathrm{H}_{2}$ consumption and $\mathrm{H}_{2} \mathrm{O}$ production stoichiometry from $\mathrm{H}_{2}$ TPR

\begin{tabular}{llllll}
\hline Catalyst & $\mathrm{Cu}(0.12)^{a}$ & $\mathrm{Cu}(0.36)$ & $\mathrm{Cu}(0.38)$ & $\mathrm{Cu}(0.58)$ & $\mathrm{Cu}(0.60)$ \\
\hline $\mathrm{H}_{2} / \mathrm{Cu}$ & & & & & \\
Peak 1 & 0.51 & 0.48 & 0.44 & 0.45 & 0.48 \\
Peak 2 & 0.53 & 0.50 & 0.53 & 0.52 & 0.53 \\
Total & 1.04 & 0.98 & 0.97 & 0.97 & 1.01 \\
$\mathrm{H}_{2} \mathrm{O} / \mathrm{Cu}$ & 0.26 & 0.30 & 0.31 & 0.45 & 0.46 \\
$\mathrm{H}_{2} \mathrm{O} / \mathrm{H}_{2}$ & 0.49 & 0.60 & 0.58 & 0.86 & 0.88 \\
$($ 2nd peak $)$ & & & & \\
${ }^{a}$ Molar ratio of Cu to total Al. & & & \\
\hline
\end{tabular}

$0.46 \mathrm{H}_{2} \mathrm{O} / \mathrm{Cu}$ for the various samples and it increases with increasing $\mathrm{Cu} / \mathrm{Al}$ ratio (Table 2). $\mathrm{H}_{2} \mathrm{O}$ can form via removal of oxygen atoms from oxygen-containing $\mathrm{Cu}$ species, but also via recombination of zeolitic $\mathrm{OH}$ groups during incipient dealumination of the zeolite. Before reduction of $\mathrm{Cu}^{+}$species, negligible amounts of $\mathrm{OH}$ groups exist at exchange sites, but vicinal $\mathrm{OH}$ groups form via subsequent reduction of $\mathrm{Cu}^{+}$species, which were in turn formed via reduction of oxygenbridged $\mathrm{Cu}^{2+}$ dimers and isolated $\mathrm{Cu}^{2+}$. The measured $\mathrm{H}_{2} \mathrm{O}$ amounts contain $\mathrm{H}_{2} \mathrm{O}$ formed both from reduction of $\mathrm{Cu}$ dimers and from dealumination of the zeolite; therefore, these measurements overestimate slightly the number of removable oxygen atoms from $\mathrm{Cu}$ species.

Next, we consider the stoichiometry for the complete reduction of each of the four species shown in Fig. 1 in order to probe their potential respective contributions to the two reduction peaks shown in Fig. 2. The stoichiometries expected for the various $\mathrm{Cu}$ species in Fig. 1 are shown in eqns. (1)-(4) (in Table 3). All four species start as $\mathrm{Cu}^{2+}$ species and reduce to $\mathrm{Cu}^{0}$ with equal amounts of hydrogen consumption $\left(\mathrm{H}_{2} /\right.$ $\mathrm{Cu}=1)$. Thus, these four species differ only in their relative rates of $\mathrm{H}_{2} \mathrm{O}$ formation and in their oxygen content.

The area under the high-temperature $\mathrm{H}_{2}$ consumption is similar in all samples $\left(\mathrm{H}_{2} / \mathrm{Cu}=0.50-0.53\right)$, but that of the coincident $\mathrm{H}_{2} \mathrm{O}$ evolution peak differs among samples with different $\mathrm{Cu} / \mathrm{Al}$ ratios (Table 2). This indicates that only some of the $\mathrm{H}_{2}$ consumed in this peak leads to the $\mathrm{H}_{2} \mathrm{O}$ formed, and that $\mathrm{H}_{2}$ is used to reduce more than one type of $\mathrm{Cu}$ species, albeit with similar reduction kinetics. The $\mathrm{H}_{2} \mathrm{O} / \mathrm{Cu}$ ratio is less than 0.5 for all samples, which precludes the exclusive presence of dimers and $\mathrm{CuO}$, which would lead to $\mathrm{H}_{2} \mathrm{O} / \mathrm{Cu}$ ratios of 0.5 and 1 (eqns. (1)-(4) in Table 3), respectively. Thus, $\mathrm{Cu}^{2+}$ monomers at exchange sites, which would reduce to $\mathrm{Cu}^{0}$ with the concurrent formation of protons (but not $\mathrm{H}_{2} \mathrm{O}$ ), must be present in all $\mathrm{Cu}-\mathrm{ZSM} 5$ samples. If crystalline $\mathrm{CuO}$ were present, its reduction would occur at relatively low temperatures $(\sim 500 \mathrm{~K}),{ }^{20}$ and its coincidence with the $\mathrm{H}_{2} \mathrm{O}$ evolution peak from dimers would be unlikely. The $\mathrm{H}_{2} \mathrm{O} / \mathrm{Cu}$ ratio increases with increasing $\mathrm{Cu} / \mathrm{Al}$ ratio (Table 2), suggesting that the oxygen removed as $\mathrm{H}_{2} \mathrm{O}$ arises from $\mathrm{Cu}$ species that become more abundant as the distance among $\mathrm{Cu}$ cations decreases. This is consistent with the expected prevalence of $\mathrm{Cu}$ dimers as $\mathrm{Cu} / \mathrm{Al}$ ratios increase. The only other species with extraframework oxygen atoms is $\left\{\mathrm{Cu}^{2+}(\mathrm{OH})^{-}\right\}^{+}$, but its relative abundance should decrease as the probability of finding isolated $\mathrm{Cu}$ species decreases with increasing $\mathrm{Cu} / \mathrm{Al}$ ratio; moreover, the reduction of $\left\{\mathrm{Cu}^{2+}(\mathrm{OH})^{-}\right\}^{+}$would lead to $\mathrm{H}_{2} \mathrm{O} / \mathrm{H}_{2}$ ratios of 1. The relative abundance of $\left\{\mathrm{Cu}^{2+}-\mathrm{O}^{2-}-\mathrm{Cu}^{2+}\right\}^{2+}$ dimers should increase with increasing density of $\left\{\mathrm{Cu}^{2+}(\mathrm{OH})^{-}\right\}^{+}$species initially formed during ion exchange in slightly acidic media, because such species are more likely to condense with similar species and less likely to react with a decreasing number of remaining $\mathrm{OH}$ groups to form instead $\mathrm{Cu}^{2+}$ cations bridging two exchange sites. The prevalence of dimers at higher $\mathrm{Cu} / \mathrm{Al}$ contents is consistent with the higher $\mathrm{H}_{2} \mathrm{O} / \mathrm{Cu}$ values measured at higher $\mathrm{Cu} / \mathrm{Al}$ ratios, which reflect a larger contribution from reduction events occurring that remove oxygen atoms instead of forming protons.

In view of these results, we attempt to describe $\mathrm{H}_{2}$ reduction processes (Fig. 2) using only exchanged $\mathrm{Cu}^{2+}$ and $\left\{\mathrm{Cu}^{2+}-\mathrm{O}^{2-}\right.$ $\left.\mathrm{Cu}^{2+}\right\}^{2+}$ species (Fig. 3). The $\mathrm{H}_{2} / \mathrm{Cu}$ ratios $(0.50-0.53$ for all samples) from the second reduction peak indicates that this step reduces every $\mathrm{Cu}$ atom in the sample from $\mathrm{Cu}^{+}$to $\mathrm{Cu}^{0}$; in turn, this suggests the complete reduction of $\mathrm{Cu}^{2+}$ to $\mathrm{Cu}^{+}$ within the first $\mathrm{H}_{2}$ consumption peak for both $\mathrm{Cu}^{2+}$ monomers and $\left\{\mathrm{Cu}^{2+}-\mathrm{O}^{2-}-\mathrm{Cu}^{2+}\right\}^{2+}$ dimers. The incipient reduction of cations in metal oxides is often limited by the rate of initial $\mathrm{H}_{2}$ dissociation; therefore, the observed coincident reduction of two structurally distinct species within this first peak may only reflect the temperature required for the incipient 
Table 3 Stoichiometry for $\mathrm{H}_{2}$ reduction, for different copper species

\begin{tabular}{lcc}
\hline Copper species & Reaction & \\
\hline$\left\{\mathrm{Cu}^{2+}-(\mathrm{OH})^{-}\right\}^{+}$ & $\left\{\mathrm{Cu}^{2+}-(\mathrm{OH})^{-}\right\}^{+}+\mathrm{H}_{2} \rightarrow \mathrm{Cu}^{0}+\mathrm{H}^{+}+\mathrm{H}_{2} \mathrm{O}$ & $(1)$ \\
$\mathrm{Cu}^{2+}$ & $\mathrm{Cu}^{2+}+\mathrm{H}_{2} \rightarrow \mathrm{Cu}^{0}+2 \mathrm{H}^{+}$ & $(\mathrm{Cu}$ \\
Copper dimers $\left\{\mathrm{Cu}^{2+}-\mathrm{O}^{2-}-\mathrm{Cu}^{2+}\right\}^{2+}$ & 0 & $(2)$ \\
Bulk copper oxide & $\left\{\mathrm{Cu}^{2+}-\mathrm{O}^{2-}-\mathrm{Cu}^{2+}\right\}^{2+}+2 \mathrm{H}_{2} \rightarrow 2 \mathrm{Cu}^{0}+2 \mathrm{H}^{+}+\mathrm{H}_{2} \mathrm{O}$ & $(3)$ \\
& $\mathrm{CuO}+\mathrm{H}_{2} \rightarrow \mathrm{Cu}^{0}+\mathrm{H}_{2} \mathrm{O}$ & 0.5 \\
\hline
\end{tabular}

formation of $\mathrm{H}$-atoms required for the reduction of both types of $\mathrm{Cu}$ species.

$\mathrm{H}_{2} \mathrm{O}$ desorbs only at higher temperatures, in a peak coincident with the second $\mathrm{H}_{2}$ reduction peak. This water is not just adsorbed on ZSM5, because during initial pretreatments in oxygen or $\mathrm{He}, \mathrm{H}_{2} \mathrm{O}$ evolves at much lower temperatures (350-400 K). Yet, during $\mathrm{H}_{2}$-TPR, water does not desorb after $\mathrm{Cu}^{2+}$ is reduced to $\mathrm{Cu}^{+}$, apparently because of the presence of a $\mathrm{H}_{2} \mathrm{O}$ binding site on the $\mathrm{Cu}^{+}$species formed. As $\mathrm{Cu}^{+}$is subsequently reduced to $\mathrm{Cu}^{0}$, this binding site is destroyed and all of the water formed during reduction desorbs at the same temperature (and apparently via the same kinetic process) as the second $\mathrm{H}_{2}$ consumption peak.

\section{$\mathrm{X}$-Ray absorption spectroscopy during reduction of $\mathrm{Cu}$-ZSM5 in $\mathrm{H}_{2}$}

These conclusions were confirmed by X-ray absorption spectra measured during treatment in $\mathrm{H}_{2}$. The near-edge spectral region is sensitive to the $\mathrm{Cu}$ oxidation state. ${ }^{9-11,34-38}$ Fig. $4 \mathrm{a}$ and $4 \mathrm{~b}$ shows near-edge spectra for $\mathrm{Cu}(0.38)$ during reduction in $\mathrm{H}_{2}$ at increasing temperatures. Two spectral features (labeled (I) and (II); Fig. 4a and 4b) changed during $\mathrm{H}_{2}$ treatment. The intensity of (I) increased with temperature up to $523 \mathrm{~K}$, as (II) became weaker (Fig. 4a). Between $523 \mathrm{~K}$ and $800 \mathrm{~K}$, (I) became less intense and ultimately disappeared (Fig. 4b), suggesting a change in the oxidation state of $\mathrm{Cu}$ atoms. These changes in the near-edge spectra may reflect the reduction of $\mathrm{Cu}^{2+}$ to $\mathrm{Cu}^{+}$and then to $\mathrm{Cu}^{0}$. In fact, the feature at $8983-8984 \mathrm{eV}$ for species (I) has been assigned to dipole-allowed $1 \mathrm{~s} \rightarrow 4 \mathrm{p}$ electronic transitions in $\mathrm{Cu}^{+} .9,34-39$ In contrast, $\mathrm{Cu}^{2+}$ species show three features in the near-edge region: a weak absorption at about $8978 \mathrm{eV}$, attributed to dipole-forbidden 1s $\rightarrow$ 3d transitions and a shoulder at $8988 \mathrm{eV}$ and an intense peak at 8998 $\mathrm{eV}$, both arising from $1 \mathrm{~s} \rightarrow 4 \mathrm{p}$ transitions. ${ }^{9,34-39}$ During reduction, additional electrons are placed onto unoccupied $\mathrm{Cu}$ atomic orbitals, leading to changes in the probability of core s-electron transitions into these valence bound states. ${ }^{35}$

Near-edge X-ray absorption spectra for $\mathrm{Cu}(0.38)$ (Spectra A-C) and for a $\mathrm{Cu}$ foil (Spectrum D) are shown in Fig. 5.
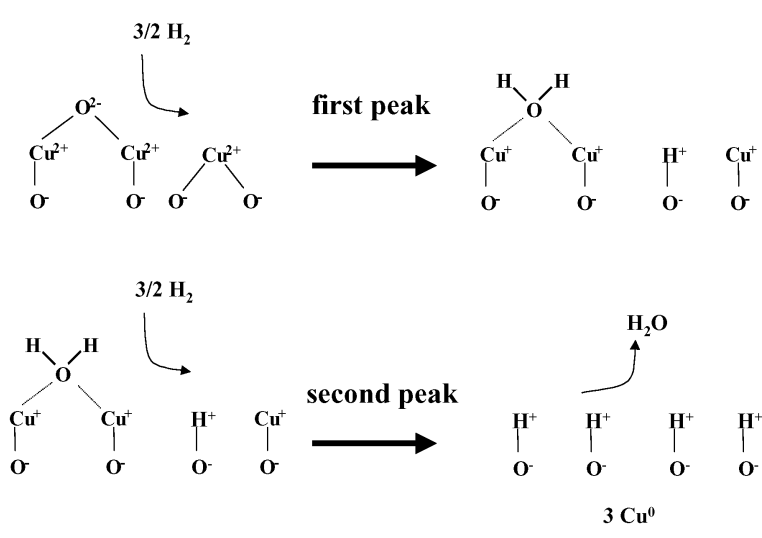

Fig. 3 Stoichiometry and pathways for reduction of $\mathrm{Cu}^{2+}$ and $\left\{\mathrm{Cu}^{2+}-\mathrm{O}^{2-}-\mathrm{Cu}^{2+}\right\}^{2+}$ in $\mathrm{Cu}-\mathrm{ZSM}-5$ using $\mathrm{H}_{2}$ as the reductant.
No significant features were detected in the $\mathrm{Cu}(0.38)$ sample exposed to ambient air (Spectrum A), apparently as a result of significant structural distortion by coordinated water, which provides confirming evidence for the dispersed nature of $\mathrm{Cu}^{2+}$ species in fresh samples. In contrast, the spectra during treatment in $\mathrm{O}_{2}$ showed features corresponding to $\mathrm{Cu}^{2+}$ (Spectrum B). Spectrum $\mathrm{C}$ corresponds to the sample $(\mathrm{Cu}(0.38))$ after reduction in $\mathrm{H}_{2}$ at $523 \mathrm{~K}$, a temperature that lies between the two $\mathrm{H}_{2}$ consumption peaks (Fig. 2). Spectrum $\mathrm{C}$ has a distinct feature that is absent in Spectra $\mathrm{B}$ and $\mathrm{D}$ and which has been attributed to $\mathrm{Cu}^{+}$species. ${ }^{10,34}$

The two well-defined and equimolar $\mathrm{H}_{2}$ consumption peaks during $\mathrm{H}_{2}$ reduction (Fig. 2) suggest that reduction occurs in two sequential and well-defined one-electron reduction steps leading to $\mathrm{Cu}^{0}$ at the end of the process. This sequential $\mathrm{Cu}^{2+} \rightarrow \mathrm{Cu}^{+} \rightarrow \mathrm{Cu}^{0}$ process is consistent with the near-edge spectra in Fig. 5 and with the transient evolution of the near-edge spectra (Figs. $4 \mathrm{a}$ and $4 \mathrm{~b}$ ). Feature (I) at $\sim 8983 \mathrm{eV}$, attributed to $\mathrm{Cu}^{+}$, first increased and then decreased with increasing temperature. The magnitude of these changes was estimated by linear combination methods using the starting spectrum, the intermediate spectrum between the two reduction peaks, and $\mathrm{Cu}$ foil as standards for $\mathrm{Cu}^{2+}, \mathrm{Cu}^{+}$, and $\mathrm{Cu}^{0}$ species, respectively. The corresponding fitted spectra for two samples are shown in Fig. 6, along with the experimental
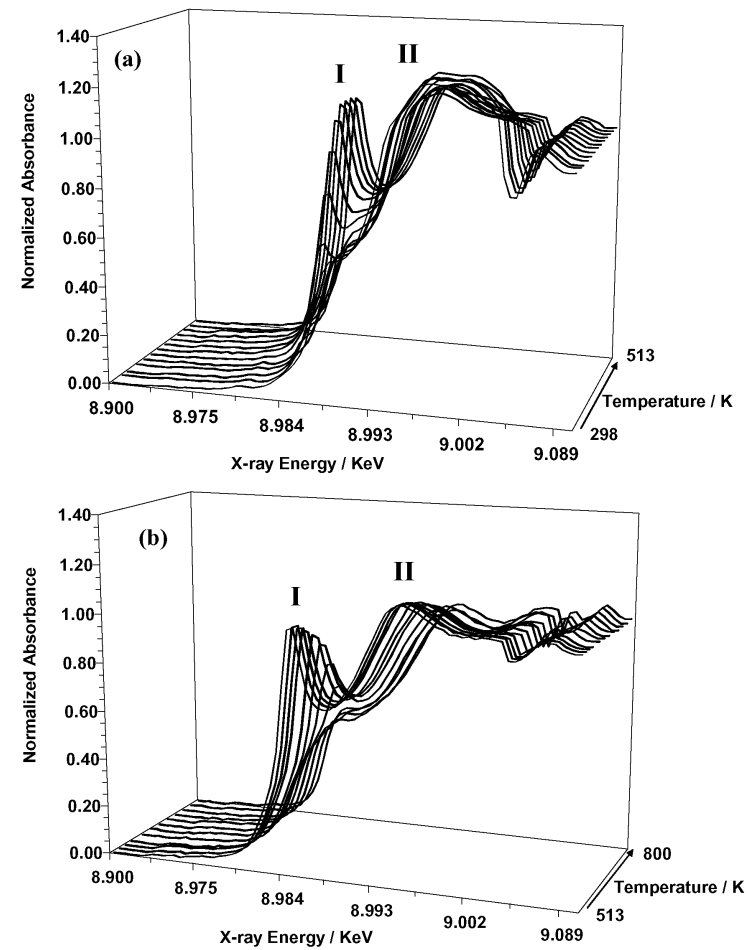

Fig. 4 X-ray absorption near-edge spectra after in situ temperature programmed reduction of $\mathrm{Cu}(0.38)$ in $5 \% \mathrm{H}_{2} / \mathrm{Ar}$ (a) from room temperature to $523 \mathrm{~K}$ and (b) from $523 \mathrm{~K}$ to $823 \mathrm{~K}$ at $0.067 \mathrm{~K} \mathrm{~s}^{-1}$. The energy-scale is expanded between 8.975 and $9.002 \mathrm{keV}$ in order to show the edge region in greater detail. 


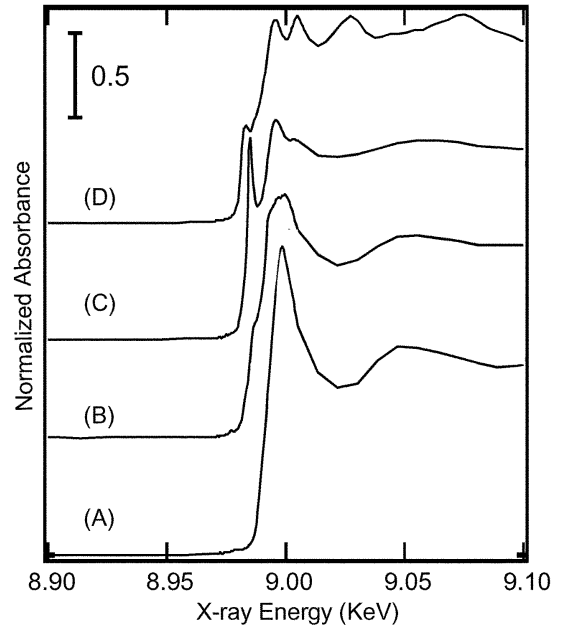

Fig. 5 X-ray absorption near-edge spectra, (A) $\mathrm{Cu}(0.38)$ fresh exposed to ambient air, (B) $\mathrm{Cu}(0.38)$ in $50 \% \mathrm{O}_{2} / \mathrm{He}$ at $773 \mathrm{~K}$, (C) $\mathrm{Cu}(0.38)$ in $5 \% \mathrm{H}_{2} / \mathrm{Ar}$ at $523 \mathrm{~K}$, (D) reference $\mathrm{Cu}$ foil at $298 \mathrm{~K}$.

spectra. During $\mathrm{H}_{2}$ treatment at $475 \mathrm{~K}$ (Fig. 6a), the sample consists of nearly equimolar amounts of $\mathrm{Cu}^{2+}$ and $\mathrm{Cu}^{+}$, while at $648 \mathrm{~K}$ (Fig. 6b), the $\mathrm{Cu}^{+}$fraction is $\sim 0.75$. From the good agreement between the experimental and fitted spectra, it is clear that the intermediate spectra can be represented accurately by linear combinations of the standard spectra.

The evolution of the various $\mathrm{Cu}$ species estimated from these linear combination analysis methods can be compared with the rates of $\mathrm{H}_{2}$ consumption and $\mathrm{H}_{2} \mathrm{O}$ evolution measured from mass spectrometric analysis of the effluent during reduction in $\mathrm{H}_{2}$ (Fig. 7). Fig. 7a and 7c show the $\mathrm{H}_{2}$-TPR profiles and the relative amounts of each $\mathrm{Cu}$ species obtained from the X-ray absorption spectra for $\mathrm{Cu}(0.38)$; Fig. $7 \mathrm{~b}$ and $7 \mathrm{~d}$ show the corresponding data for $\mathrm{Cu}(0.12)$. Principal component

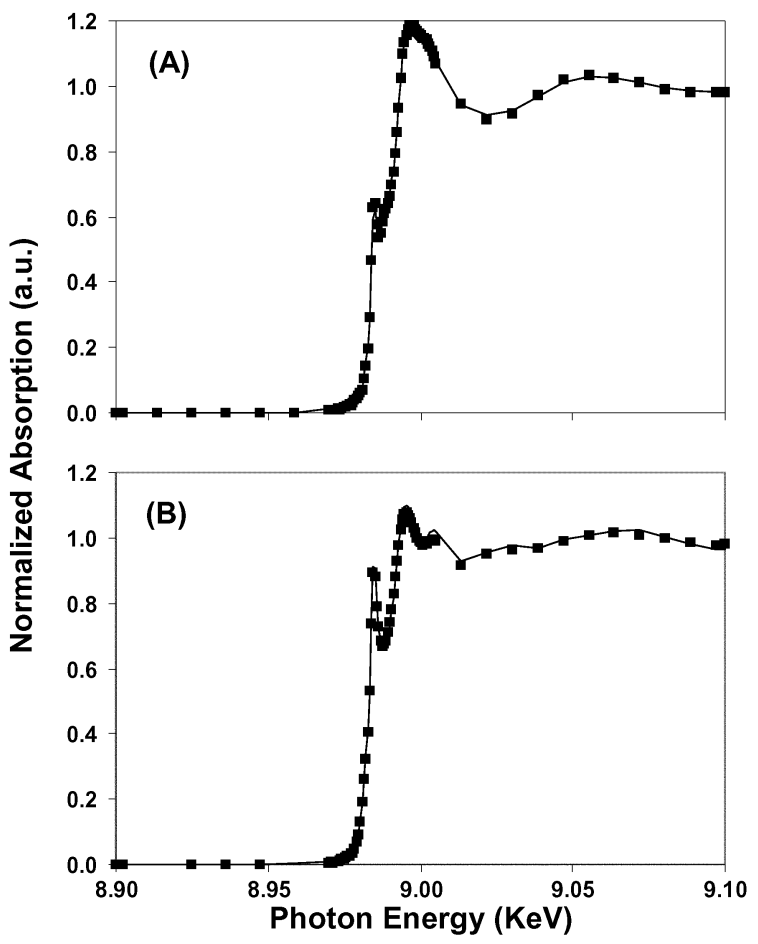

Fig. 6 Linear combination fit of X-ray absorption near-edge spectra during in-situ temperature programmed reduction in $5 \% \mathrm{H}_{2} / \mathrm{Ar}$ of $\mathrm{Cu}(0.38)$ at (A) $475 \mathrm{~K}$ and (B) $648 \mathrm{~K}$. Lines represent the fitted spectra and $\square$ represent experimental spectra.

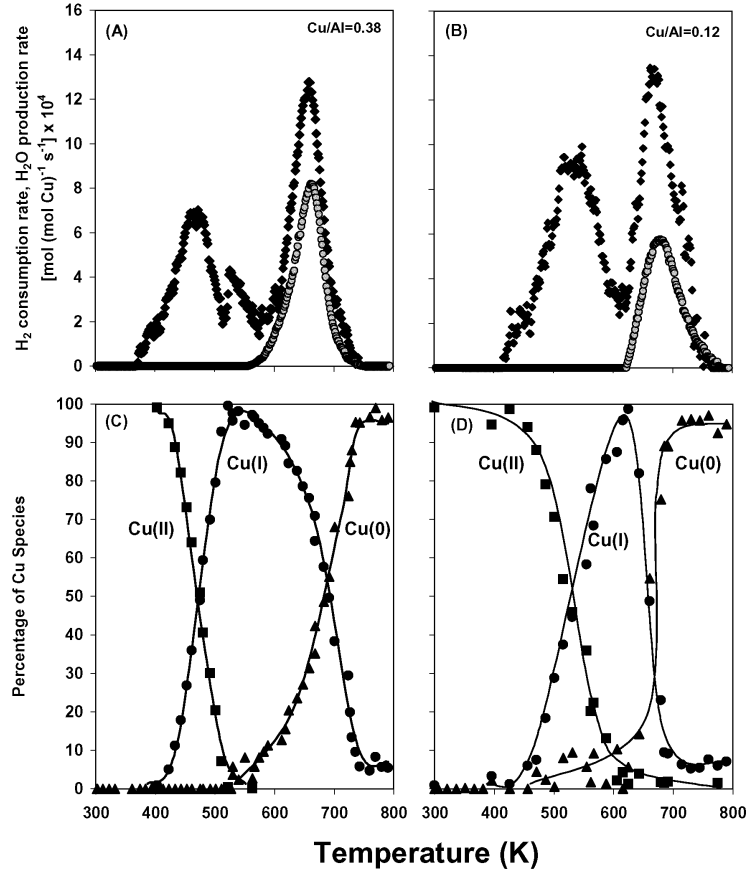

Fig. 7 Comparison between $\mathrm{H}_{2}$ consumption rates and principal component analysis deconvolution of X-ray absorption near-edge spectra during in situ temperature programmed reduction of $\mathrm{Cu}(0.38)$ (A) and (C) and $\mathrm{Cu}(0.12)$ (B) and (D). For (A) and (B), represents the hydrogen consumption rate, and $\bigcirc$ represents the $\mathrm{H}_{2} \mathrm{O}$ production rate. For (C) and (D), $\mathbf{\square}$ represents $\mathrm{Cu}(\mathrm{II})$, $\bullet$ represents $\mathrm{Cu}(\mathrm{I}), \Delta$ represents $\mathrm{Cu}(0)$.

analysis showed that these are complete fits for $\mathrm{Cu}(0.38)$, without any omitted structures and with all the $\mathrm{Cu}^{2+}$ species initially present converted fully to $\mathrm{Cu}^{0}$ by the final temperature.

The structural description of $\mathrm{Cu}(0.12)$ is less straightforward than for $\mathrm{Cu}(0.38)$. Principal component analysis suggests that the $\mathrm{Cu}(0.12)$ starting material contains more structural features than $\mathrm{Cu}(0.38)$ or that the structures of these $\mathrm{Cu}^{2+}$ species change with temperature. The $\mathrm{Cu}^{+}$intermediate formed at $\sim 620 \mathrm{~K}$ in $\mathrm{Cu}(0.12)$ is identical in structure to that formed in $\mathrm{Cu}(0.38)$ at the same temperature and it accounts for all of the initial $\mathrm{Cu}^{2+}$ in the starting material. As also suggested by Fig. $4, \mathrm{Cu}^{+}$reaches a maximum concentration near the end of the low-temperature $\mathrm{H}_{2}$ consumption peak. After the high temperature reduction peak (at $\sim 800 \mathrm{~K}$ ), the sample is more than $95 \% \mathrm{Cu}^{0}$. This apparent incomplete conversion reflects differences in the near-edge spectrum between the $\mathrm{Cu}$ foil standard and the small $\mathrm{Cu}^{0}$ clusters likely to form after reduction of exchanged $\mathrm{Cu}$ cations, and not the incomplete reduction of these $\mathrm{Cu}$ species. This was confirmed by extended $\mathrm{X}$-ray absorption fine-structure (EXAFS) analysis. $\mathrm{Cu}$ atoms in metal clusters formed during reduction at $\sim 550-750 \mathrm{~K}$ showed a $\mathrm{Cu}-\mathrm{Cu}$ first-shell coordination number of $6-7 . \mathrm{Cu}$ atoms in a $7.6 \AA$ cluster with one core $\mathrm{Cu}$ atom and a complete shell of 12 neighbors would have an average $\mathrm{Cu}-\mathrm{Cu}$ coordination number of 5.5. This suggests that the $\mathrm{Cu}$ metal clusters are small $(\sim 10 \AA)$ and completely reduced after treatment in $\mathrm{H}_{2}$ at $\sim 800 \mathrm{~K}$.

Reduction of $\mathrm{Cu}^{2+}$ species in $\mathrm{Cu}-\mathrm{ZSM} 5$ using $\mathrm{CO}$ and further reduction in $\mathrm{H}_{2}$ after $\mathrm{CO}$ treatment

The number of $\mathrm{Cu}$ species with removable oxygens (e.g., $\mathrm{CuO}$ and $\mathrm{Cu}$ dimers) were also measured from the evolution of $\mathrm{CO}_{2}$ during reduction of $\mathrm{Cu}-\mathrm{ZSM} 5$ in $\mathrm{CO}$, as also reported previously. ${ }^{20}$ The $\mathrm{H}_{2}$-TPR data showed that $\mathrm{CuO}$ clusters were not present and that removable oxygen atoms were exclusively 
associated with $\left\{\mathrm{Cu}^{2+}-\mathrm{O}^{2-}-\mathrm{Cu}^{2+}\right\}^{2+}$ dimers. $\mathrm{Cu}^{2+}$ monomers cannot reduce with $\mathrm{CO}$, because protons are unavailable for the required charge balance. Thus, $\mathrm{CO}_{2}$ forms only from oxygen atoms in $\left\{\mathrm{Cu}^{2+}-\mathrm{O}^{2-}-\mathrm{Cu}^{2+}\right\}^{2+}$ species via the reaction:

$$
\left\{\mathrm{Cu}^{2+}-\mathrm{O}^{2-}-\mathrm{Cu}^{2+}\right\}^{2+}+\mathrm{CO} \rightarrow 2 \mathrm{Cu}^{+}+\mathrm{CO}_{2}
$$

The amount of $\mathrm{CO}_{2}$ formed reflects the number of $\mathrm{Cu}$ dimers in each sample.

$\mathrm{CO}_{2}$ formation rates on $\mathrm{Cu}(0.38), \mathrm{Cu}(0.58), \mathrm{Cu}(0.12)$, $\mathrm{Cu}(0.36)$, and $\mathrm{Cu}(0.60)$ are shown in Fig. 8 as a function of temperature. The onset of reduction is $\sim 320 \mathrm{~K}$ for all of the catalysts except in $\mathrm{Cu}(0.12)$, for which the reduction begins at $\sim 380 \mathrm{~K}$. Poorly resolved features were detected between $350 \mathrm{~K}$ and $650 \mathrm{~K}$ in all samples; they appear to include two or three unresolved peaks, in contrast with the two distinct peaks previously reported at $\sim 400 \mathrm{~K}$ and $\sim 550 \mathrm{~K}$ for $\mathrm{Cu} / \mathrm{Al}$ ratios similar to those in the present study. ${ }^{18,20}$ These two peaks were assigned to $\left\{\mathrm{Cu}^{2+}-\mathrm{O}^{2-}-\mathrm{Cu}^{2+}\right\}^{2+}$ and $\mathrm{CuO}$, respectively, but our data are not consistent with these conclusions, because our samples lack $\mathrm{CuO}$ clusters, but yet exhibit similarly complex reduction behavior. The broad maximum in these features shifts from $\sim 450 \mathrm{~K}$ for $\mathrm{Cu}(0.38)$ and $\mathrm{Cu}(0.58)$ to $\sim 550 \mathrm{~K}$ on $\mathrm{Cu}(0.60)$.

The formation of $\mathrm{CO}_{2}$ requires $\mathrm{CO}$ adsorption and reaction with oxygen atoms in $\left\{\mathrm{Cu}^{2+}-\mathrm{O}^{2-}-\mathrm{Cu}^{2+}\right\}^{2+}$. The broad $\mathrm{CO}_{2}$ evolution profile may reflect the presence of $\left\{\mathrm{Cu}^{2+}-\mathrm{O}^{2-}\right.$ $\left.\mathrm{Cu}^{2+}\right\}^{2+}$ dimers with different reactivity towards $\mathrm{CO}$, either because of their local coordination to two exchange sites of varying structure or because of their non-uniform distances from $\mathrm{CO}$ adsorption sites. In contrast, all dimers, and even the $\mathrm{Cu}^{2+}$ monomers, reduced to $\mathrm{Cu}^{+}$in a single narrow peak when $\mathrm{H}_{2}$ was used as a reductant, apparently because reduction with $\mathrm{H}_{2}$ is controlled by the kinetics of $\mathrm{H}_{2}$ dissociation, and not by the non-uniform reactivity of $\mathrm{Cu}$ cations with the spilled-over hydrogen atoms. The non-uniform reactivity of $\left\{\mathrm{Cu}^{2+}-\mathrm{O}^{2-}-\mathrm{Cu}^{2+}\right\}^{2+}$ structures inferred from the broad $\mathrm{CO}$ reduction profiles is confirmed below from the non-reactive desorption of $\mathrm{O}_{2}$ from such structures.

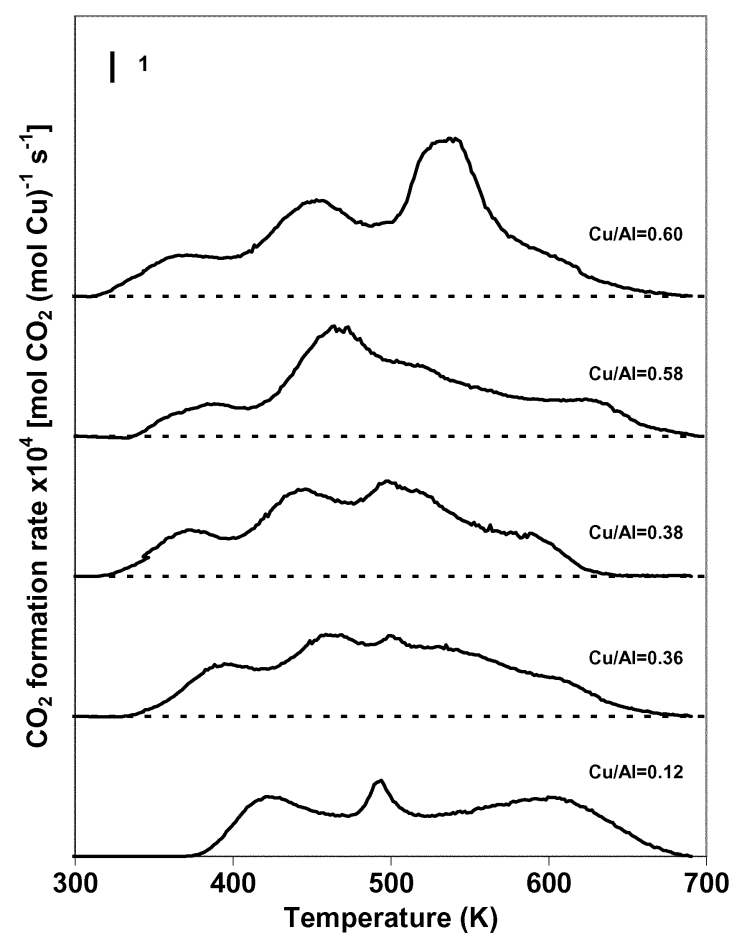

Fig. $8 \mathrm{CO}_{2}$ formation rates during temperature programmed reduction in $1 \% \mathrm{CO} / \mathrm{He}\left(0.5 \mathrm{~cm}^{3} \mathrm{~s}^{-1}\right)$ as a function of temperature $(0.167$ $\left.\mathrm{K} \mathrm{s}^{-1}\right)$ for all $\mathrm{Cu} / \mathrm{Al}$ ratios $(0.2 \mathrm{~g})$.
Table 4 Oxygen removal calculation from CO-TPR and comparison with the $\mathrm{H}_{2}$-TPR on oxygen treated samples

\begin{tabular}{llllll}
\hline Catalyst & $\mathrm{Cu}(0.12)$ & $\mathrm{Cu}(0.36)$ & $\mathrm{Cu}(0.38)$ & $\mathrm{Cu}(0.58)$ & $\mathrm{Cu}(0.60)$ \\
\hline $\mathrm{CO}_{2} / \mathrm{Cu}$ from & 0.23 & 0.28 & 0.30 & 0.35 & 0.39 \\
$\mathrm{CO}-\mathrm{TPR}$ & & & & & \\
$\mathrm{O} / \mathrm{Cu}$ from & 0.23 & 0.28 & 0.30 & 0.35 & 0.39 \\
$\mathrm{CO}-\mathrm{TPR}^{a}$ & & & & & \\
$\mathrm{Cu}_{\text {dimer }} / \mathrm{Cu}$ & 0.46 & 0.56 & 0.60 & 0.70 & 0.78 \\
$\mathrm{Cu}_{\text {dimer }} / \mathrm{Al}$ & 0.055 & 0.20 & 0.23 & 0.41 & 0.47 \\
$\mathrm{Cu}^{2+} / \mathrm{Al}$ & 0.065 & 0.16 & 0.15 & 0.17 & 0.13 \\
$(\mathrm{O} / \mathrm{Cu})^{a} /$ & 0.88 & 0.93 & 0.97 & 0.78 & 0.85
\end{tabular}

$(\mathrm{O} / \mathrm{Cu})^{b c}$

${ }^{a}$ Oxygen per total copper measured from the CO-TPR (final temperature $700 \mathrm{~K}$ ). ${ }^{b}$ Oxygen per total copper measured from the $\mathrm{H}_{2}$-TPR (final temperature $800 \mathrm{~K}$ ). ${ }^{c}$ Ratio of the oxygen removal during the CO-TPR and the $\mathrm{H}_{2}$-TPR

The $\mathrm{CO}_{2} / \mathrm{Cu}$ ratios during reduction of $\mathrm{Cu}-\mathrm{ZSM} 5$ by $\mathrm{CO}$ range from 0.23 for the low $\mathrm{Cu} / \mathrm{Al}$ ratio sample to 0.39 for the sample with highest $\mathrm{Cu} / \mathrm{Al}$ ratio (Table 4). The number of O-atoms removed as $\mathrm{CO}_{2}$ is slightly smaller than the number removed as $\mathrm{H}_{2} \mathrm{O}$ during reduction in $\mathrm{H}_{2}$, because small amounts of $\mathrm{H}_{2} \mathrm{O}$ can also be formed via condensation of zeolite $\mathrm{OH}$ groups, as vicinal $\mathrm{OH}$ groups form during reduction of $\left\{\mathrm{Cu}^{2+}-\mathrm{O}^{2-}-\mathrm{Cu}^{2+}\right\}^{2+}$. As a result, $\mathrm{CO}_{2} / \mathrm{Cu}$ ratios provide a more direct measurement of the number of $\mathrm{Cu}$ dimers than $\mathrm{H}_{2} \mathrm{O} / \mathrm{Cu}$ ratios. The $\mathrm{Cu}_{\text {dimer }} / \mathrm{Cu}$ fraction is twice the value of this $\mathrm{CO}_{2} / \mathrm{Cu}$ ratio because each $\mathrm{O}$-atom is associated with $2 \mathrm{Cu}$ atoms. We conclude that between $46 \%$ and $78 \%$ of the $\mathrm{Cu}$ atoms are present as $\mathrm{Cu}$ dimers in our samples (Table 4); this percentage increases with increasing $\mathrm{Cu} / \mathrm{Al}$ ratio, as expected from the shorter average distance among $\mathrm{Cu}$ atoms at higher $\mathrm{Cu} / \mathrm{Al}$ ratios.

These conclusions about $\mathrm{Cu}$ speciation were confirmed by reducing samples in $\mathrm{H}_{2}$ after $\mathrm{CO}-\mathrm{TPR}$ (and cooling in $\mathrm{CO}$ to ambient temperature). The $\mathrm{H}_{2}$ consumption, $\mathrm{H}_{2} \mathrm{O}$ formation, and $\mathrm{CO}$ desorption rates are shown in Fig. 9 for $\mathrm{Cu}(0.36)$. Two $\mathrm{H}_{2}$ consumption peaks were observed (at $\sim 600 \mathrm{~K}$ and $\sim 750 \mathrm{~K}$ ), while $\mathrm{H}_{2}$-TPR studies after CO-TPR previously reported a single reduction peak at $800 \mathrm{~K}, .{ }^{18,20}$ This peak was attributed to reduction of $\mathrm{Cu}^{+}$species formed via reactions of $\mathrm{Cu}^{2+}$ monomers with $\mathrm{Cu}$ metal species, which had been formed by reduction of $\mathrm{CuO}$ to $\mathrm{Cu}$ using $\mathrm{CO} .{ }^{20}$ These complex pathways would require the migration of $\mathrm{Cu}$ metal at relatively low temperatures and would not occur when $\mathrm{CuO}$ clusters are not present. The two $\mathrm{H}_{2}$ consumption peaks appear at slightly higher temperatures (Fig. 9) than during reduction of fresh samples in $\mathrm{H}_{2}$ (Fig. 2). This reflects the adsorption of $\mathrm{CO}$ on $\mathrm{Cu}^{+}$, as previously detected by infrared spectroscopy. ${ }^{18,40}$ During $\mathrm{H}_{2}$-TPR, CO desorbs at $\sim 700 \mathrm{~K}$ (see insert in Fig. 9), immediately before the second $\mathrm{H}_{2}$ consumption peak. Thus, the stability of $\mathrm{Cu}^{+}(\mathrm{CO})$ appears to delay the onset of reduction compared to free $\mathrm{Cu}^{+}$cations. Below, we show that the amounts of $\mathrm{H}_{2}$ consumed, of $\mathrm{H}_{2} \mathrm{O}$ formed, and of $\mathrm{CO}$ desorbed during $\mathrm{H}_{2}$-TPR are consistent with the $\mathrm{Cu}$ distribution measured from $\mathrm{CO}$ reduction.

The first $\mathrm{H}_{2}$ consumption peak during reduction of air-treated samples in $\mathrm{H}_{2}$ (Fig. 2) corresponds to the reduction of both $\left\{\mathrm{Cu}^{2+}-\mathrm{O}^{2-}-\mathrm{Cu}^{2+}\right\}^{2+}$ and $\mathrm{Cu}^{2+}$ monomers to $\mathrm{Cu}^{+}$. During reduction in $\mathrm{CO}$, all $\left\{\mathrm{Cu}^{2+}-\mathrm{O}^{2-}-\mathrm{Cu}^{2+}\right\}^{2+}$ species can reduce to $\mathrm{Cu}^{+}$, but $\mathrm{Cu}^{2+}$ monomers remain as divalent cations. Thus, the first $\mathrm{H}_{2}$ consumption peak in samples pre-treated in $\mathrm{CO}$ (Fig. 9) must reflect the reduction of $\mathrm{Cu}^{2+}$ monomers. The area under this peak provides an independent estimate of the fraction of $\mathrm{Cu}^{2+}$ initially present as monomers. These monomer $\mathrm{Cu}^{2+} / \mathrm{Cu}_{\text {total }}$ estimates are 0.38 for $\mathrm{Cu}(0.36)$, in relatively good agreement with the value of 0.44 measured from $\mathrm{CO}$ 


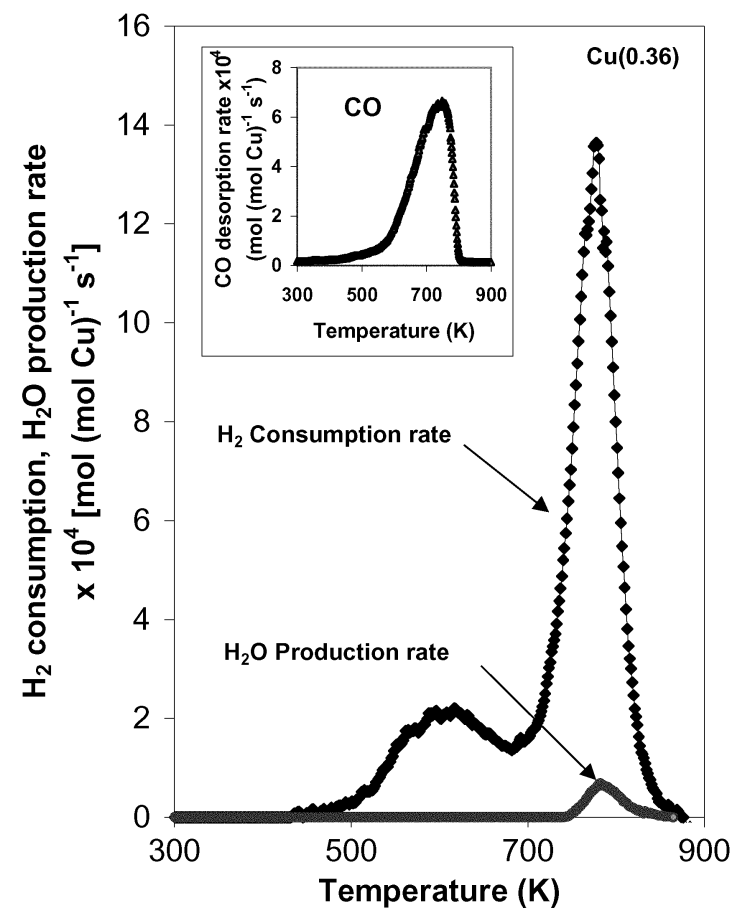

Fig. 9 Temperature programmed reduction in $5 \% \mathrm{H}_{2} / \mathrm{Ar}\left(0.417 \mathrm{~cm}^{3}\right.$ $\left.\mathrm{s}^{-1}\right)$ at $0.167 \mathrm{~K} \mathrm{~s}^{1}$, after CO TPR experiments in Fig. 10 for $\mathrm{Cu}(0.36)$ sample $(0.2 \mathrm{~g}),(\diamond)$ hydrogen consumption rate, and $(\bullet) \mathrm{H}_{2} \mathrm{O}$ production rate.

reduction data (Table 5). The second reduction peak in Fig. 9 gives a $\mathrm{H}_{2} / \mathrm{Cu}$ of 0.50 for $\mathrm{Cu}(0.36)$ (Table 5), as also obtained from the second $\mathrm{H}_{2}$ reduction peak in $\mathrm{O}_{2}$-treated samples. This confirms that the second peak in both cases (initial $\mathrm{H}_{2}$ reduction and $\mathrm{H}_{2}$ reduction after $\mathrm{CO}$ treatments) corresponds to the stoichiometric reduction of every $\mathrm{Cu}$ atom from $\mathrm{Cu}^{+}$to $\mathrm{Cu}^{0}$. Finally, the amount of $\mathrm{CO}$ desorbed during reduction in $\mathrm{H}_{2}$ of CO-treated samples $(0.57 \mathrm{CO} / \mathrm{Cu}$; Fig. 9) is almost identical to the number of $\mathrm{Cu}$ atoms in dimers estimated from $\mathrm{CO}$ reduction of this sample after air treatment $\left(0.56 \mathrm{Cu}_{\text {dimer }} /\right.$ $\mathrm{Cu}$ ) (Table 5). This confirms that all $\mathrm{Cu}$-dimers are reduced to vicinal $\mathrm{Cu}^{+}$species during CO-TPR at $700 \mathrm{~K}$, and that each of these $\mathrm{Cu}^{+}$adsorbs one $\mathrm{CO}$ during cooling to ambient temperature in $\mathrm{CO}$.

A small amount of $\mathrm{H}_{2} \mathrm{O}$ desorbs concurrently with the second $\mathrm{H}_{2}$ consumption peak (Fig. 9). This appears at first glance to contradict the conclusion that all $\mathrm{O}$ atoms in $\left\{\mathrm{Cu}^{2+}-\mathrm{O}^{2-}\right.$ $\left.\mathrm{Cu}^{2+}\right\}^{2+}$ were removed during the preceding treatment in CO. The reduction of $\mathrm{Cu}^{+}$(ex-dimers) to $\mathrm{Cu}^{0}$ and also of isolated $\mathrm{Cu}^{2+}$ to $\mathrm{Cu}^{0}$ with $\mathrm{H}_{2}$ leads to the formation of $\mathrm{OH}$ groups as vicinal pairs; these vicinal $\mathrm{OH}$ groups can readily react to form $\mathrm{H}_{2} \mathrm{O}$ in condensation reactions that remove framework oxygens and lead to incipient zeolite dealumination. This process also occurs during reduction of fresh samples in $\mathrm{H}_{2}$ and it is responsible for the slightly larger amounts of oxygen removed during reduction in $\mathrm{H}_{2}$ compared with the amounts of oxygen removed by reduction in $\mathrm{CO}$. We can bring the results of $\mathrm{H}_{2}$ and $\mathrm{CO}$ reduction measurements into excellent agreement by subtracting the amount of $\mathrm{H}_{2} \mathrm{O}$ formed via dehydroxylation from the corresponding amounts formed during reduction in $\mathrm{H}_{2}$. After this correction, the amount of oxygen removed as water from dimers using $\mathrm{H}_{2}$ is $0.275 \mathrm{H}_{2} \mathrm{O} / \mathrm{Cu}$, while that removed by $\mathrm{CO}$ as $\mathrm{CO}_{2}$ is 0.280 $\mathrm{CO}_{2} / \mathrm{Cu}$.

The results of these three types of experiments $\left(\mathrm{H}_{2}-\mathrm{TPR}\right.$, CO-TPR, and $\mathrm{H}_{2}$-TPR after CO-TPR) and the amounts of $\mathrm{CO}$ adsorbed on CO-treated samples provide a remarkably consistent picture of the $\mathrm{Cu}$ speciation in these samples. The distribution of $\mathrm{Cu}$ species is also consistent with the expected distribution of $\mathrm{Al}-\mathrm{Al}$ next nearest neighbors in these ZSM5 samples, as discussed below.

\section{Distributions of Al-Al pairs}

The highest $\mathrm{Cu}_{\text {dimer }} / \mathrm{Al}$ ratio determined from CO-TPR measurements was 0.47 (for $\mathrm{Cu}(0.60)$ ), while the highest $\mathrm{Cu}_{\text {mono- }}$ mer/Al ratio was 0.17 (for $\mathrm{Cu}(0.58)$ ) (Table 4). Both dimers and monomers must interact with two Al sites in ZSM5. Here, we examine whether the proposed $\mathrm{Cu}$ speciation is consistent with the expected distribution of Al-Al pairs in ZSM5 samples with the $\mathrm{Si} / \mathrm{Al}$ ratios in our sample. ${ }^{41-43}$

The maximum $\mathrm{Al}-\mathrm{Al}$ distances that $\mathrm{Cu}$ monomers and $\mathrm{Cu}$ dimers can span are not directly available, so we must estimate them from $\mathrm{Cu}-\mathrm{Al}$ and $\mathrm{Cu}-\mathrm{Cu}$ distances in known $\mathrm{Cu}$ compounds. $\mathrm{Cu}-\mathrm{Al}$ distances in isolated $\mathrm{Cu}^{2+}(\mathrm{OH})^{-}$have been calculated to be $2.72 \AA^{43}$ using density functional theory methods. $\mathrm{Cu}-\mathrm{Cu}$ distances of $2.95 \AA$ have been reported in $\mathrm{CuO}$ from X-ray absorption data. ${ }^{9}$ For $\mathrm{Cu}$ dimers, estimates of $\mathrm{Al}-\mathrm{Al}$ distances through the $\mathrm{Al}-\mathrm{O}-\mathrm{Cu}-\mathrm{O}-\mathrm{Cu}-\mathrm{O}-\mathrm{Al}$ bonds depend on bond angles. Using $\mathrm{Al}-\mathrm{Cu}$ and $\mathrm{Cu}-\mathrm{Cu}$ distances cited above, the maximum $\mathrm{Al}-\mathrm{Al}$ distance for $\mathrm{Cu}$ dimers would be $\sim 8.4 \AA$ (the sum of $2.72 \AA, 2.95 \AA$, and $2.72 \AA$ ). From $\mathrm{Al}-\mathrm{Al}$ statistics ${ }^{42}$ and the $\mathrm{Si} / \mathrm{Al}$ ratio of $\sim 14$ in our samples, we conclude that $0.47 \mathrm{Cu}_{\mathrm{dimer}} / \mathrm{Al}$ (the maximum experimental value) can be located using $\mathrm{Al}-\mathrm{Al}$ distances between 5.5 and $6 \AA$ (Fig. 4 in ref. 42). Since these $\mathrm{Cu}$ dimers can use even more distant Al-Al pairs (up to $\sim 8.4 \AA$ ), the observed number of dimers can be easily accommodated within the $\mathrm{Al}-\mathrm{Al}$ pairs available in the ZSM5 samples used here.

Most $\mathrm{Cu}^{2+}$ monomers appear to prefer locations within flat 5-membered rings in ZSM5 ( $\sim 75 \%$ of the $\mathrm{Cu}^{2+}$ for random $\mathrm{Al}$ placement, and $\sim 60 \%$ for equilibrium $\mathrm{Al}$ placement). ${ }^{42}$ For a $\mathrm{Si} / \mathrm{Al}$ ratio of 14 , these flat 5-membered T-site rings have a maximum $\mathrm{M}^{2+} / \mathrm{Al}$ of 0.14 when $\mathrm{Al}$ sites are placed randomly in the ZSM5 structure and 0.09 when $\mathrm{Al}$ atoms are distributed according to their energies at various T-sites. Our monomer $\mathrm{Cu}^{2+} / \mathrm{Al}$ ratios for the samples with the highest $\mathrm{Cu}$ contents are between 0.13 and 0.17 , in agreement with the predictions for random $\mathrm{Al}$ placement. Other types of rings can also stabilize $\mathrm{Cu}^{2+}$ cations, leading to slightly higher monomer $\mathrm{Cu} / \mathrm{Al}$ ratios.

Table $5 \mathrm{Cu}$ species calculated from $\mathrm{H}_{2}$ TPR after $\mathrm{O}_{2}\left(50 \% \mathrm{O}_{2} / \mathrm{He}\right)$ or $\mathrm{CO}(1 \% \mathrm{CO} / \mathrm{He})$ treatment for the catalyst $\mathrm{Cu}(0.36)$

\begin{tabular}{lllll}
\hline & $\mathrm{O}_{2}$ pretreatment & CO TPR & Difference & Cu-dimer fraction \\
\hline $\mathrm{CO}_{2} / \mathrm{Cu}$ formed during CO TPR & 0.00 & 0.28 & 0.28 & 0.56 \\
$\mathrm{H}_{2} / \mathrm{Cu}$ consumed & & & \\
$\quad$ Peak 1 & 0.48 & 0.19 & 0.29 & 0.58 \\
$\quad \mathrm{Peak} 2$ & 0.50 & 0.50 & 0 & 0.58 \\
$\quad \mathrm{Total}$ & 0.98 & 0.69 & 0.29 & 0.55 \\
$\mathrm{H}_{2} \mathrm{O} / \mathrm{Cu}$ formed & 0.30 & 0.025 & 0.275 & 0.57 \\
$\mathrm{CO} / \mathrm{Cu}$ desorbed during $\mathrm{H}_{2}-\mathrm{TPR}$ & 0.00 & 0.57 & 0.57 & \\
\hline
\end{tabular}


The measured monomer $\mathrm{Cu}^{2+} / \mathrm{Al}$ ratios (from $\mathrm{CO}$ reduction) are relatively constant for all samples (0.13-0.17), except at the lowest $\mathrm{Cu} / \mathrm{Al}$ ratio. It appears that sites capable of stabilizing a $\mathrm{Cu}^{2+}$ saturate first during ion exchange and that further exchange titrates remaining sites too distant for monomer stabilization, but able to interact with the more distant $\mathrm{Cu}$ ions in an oxygen-bridged dimer. As the $\mathrm{Cu}$ content increases, sites capable of stabilizing these dimers are also depleted, as evidenced by asymptotic ratios of $\sim 0.60 \mathrm{Cu} / \mathrm{Al}$ obtained after multiple sequential exchanges.

The speciation of $\mathrm{Cu}$ inferred from these various methods for oxygen-treated and reduced samples lead to a relatively simple picture. Dispersed $\mathrm{Cu}^{2+}$ and $\left\{\mathrm{Cu}^{2+}-\mathrm{O}^{2-}-\mathrm{Cu}^{2+}\right\}^{2+}$ account for all $\mathrm{Cu}$ species in the samples and their relative concentrations are consistent with the expected $\mathrm{Al}-\mathrm{Al}$ radial distributions in these ZSM5 samples. In the next section, we explore the autoreduction of $\left\{\mathrm{Cu}^{2+}-\mathrm{O}^{2-}-\mathrm{Cu}^{2+}\right\}^{2+}$ and the possible existence of dimers with varying structure and reactivity.

\section{$\mathrm{O}_{2}$ Evolution and autoreduction of $\left\{\mathrm{Cu}^{2+}-\mathrm{O}^{2-}-\mathrm{Cu}^{2+}\right\}^{2+}$ in $\mathrm{He}$}

$\mathrm{O}_{2}$ evolution profiles are shown in Fig. 10 as a function of temperature for $\mathrm{Cu}-\mathrm{ZSM} 5$ samples with varying $\mathrm{Cu} / \mathrm{Al}$ ratios. For $\mathrm{Cu} / \mathrm{Al}$ ratios greater than $0.12, \mathrm{O}_{2}$ desorbs in a narrow peak at $\sim 673 \mathrm{~K}$, followed by a broader desorption feature at higher temperatures. The first peak shifts slightly to higher temperatures for $\mathrm{Cu}(0.12)(\sim 735 \mathrm{~K})$. The $\mathrm{O}_{2}$-TPD profiles for samples with $\mathrm{Cu} / \mathrm{Al}$ ratios greater than 0.12 are consistent with previous studies. ${ }^{17,44,45}$ Small $\mathrm{O}_{2}$ desorption peaks have been reported at low temperatures and may reflect low coverages of molecularly adsorbed oxygen or even the diffusion of $\mathrm{O}_{2}$ molecules within zeolite channels. ${ }^{17,44-46}$ The number of oxygen atoms removed should correspond to the number of $\left\{\mathrm{Cu}^{2+}-\mathrm{O}^{2-}-\mathrm{Cu}^{2+}\right\}^{2+}$ dimers able to recombine oxygen atoms at each temperature. The amounts of oxygen removed $(\mathrm{O} / \mathrm{Cu})$ during desorption in $\mathrm{He}$ are shown in Table 6 for all samples. For $\mathrm{Cu}(0.58)$, the $\mathrm{O} / \mathrm{Cu}$ ratio is 0.20 , in agreement with previous reports ${ }^{17}$ for $\mathrm{Cu}-\mathrm{ZSM} 5$ with similar $\mathrm{Cu} / \mathrm{Al}$

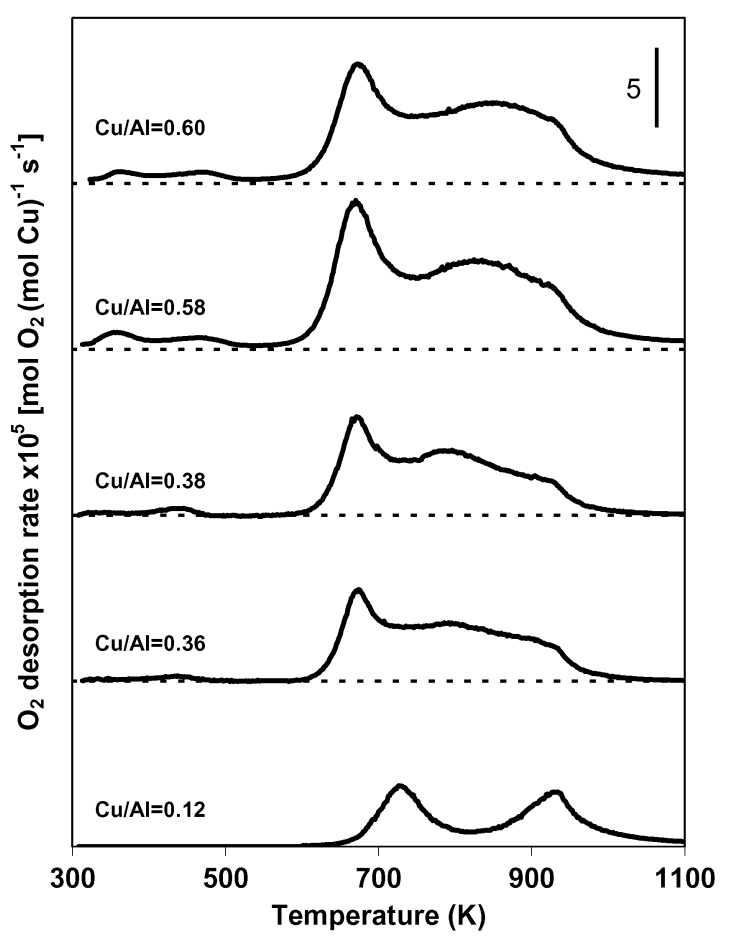

Fig. 10 Oxygen desorption rate in $\mathrm{He}\left(0.5 \mathrm{~cm}^{3} \mathrm{~s}^{-1}\right)$ as function of temperature $\left(0.167 \mathrm{~K} \mathrm{~s}^{-1}\right)$ for all the $\mathrm{Cu} / \mathrm{Al}$ catalysts $(0.2 \mathrm{~g})$, after treatment in oxygen at $773 \mathrm{~K}$.
Table 6 Oxygen removal calculation from $\mathrm{O}_{2}-\mathrm{TPD}$, and comparison with CO-TPR

\begin{tabular}{llllll}
\hline Catalyst & $\mathrm{Cu}(0.12)$ & $\mathrm{Cu}(0.36)$ & $\mathrm{Cu}(0.38)$ & $\mathrm{Cu}(0.58)$ & $\mathrm{Cu}(0.60)$ \\
\hline $\begin{array}{l}\mathrm{O} / \mathrm{Cu} \text { from } \\
\mathrm{O}_{2} \text { TPD }^{a}\end{array}$ & 0.08 & 0.13 & 0.14 & 0.20 & 0.20 \\
$\begin{array}{l}\mathrm{O} / \mathrm{Cu} \text { from } \\
\mathrm{CO}^{-T P R}{ }^{b}\end{array}$ & 0.23 & 0.28 & 0.30 & 0.35 & 0.39 \\
$\begin{array}{l}(\mathrm{O} / \mathrm{Cu})^{a} / \\
(\mathrm{O} / \mathrm{Cu})^{b c}\end{array}$ & 0.35 & 0.46 & 0.47 & 0.57 & 0.51
\end{tabular}

${ }^{a}$ Oxygen per total copper measured from the $\mathrm{O}_{2}$-TPD (final temperature $1100 \mathrm{~K}) .{ }^{b}$ Oxygen per total copper measured from the CO-TPR (final temperature $700 \mathrm{~K}$ ). ${ }^{c}$ Ratio of the oxygen removal during the $\mathrm{O}_{2}$-TPD and the CO-TPR

ratios (0.57). The $\mathrm{O} / \mathrm{Cu}$ ratios obtained from these desorption data, however, are much smaller than those obtained from the $\mathrm{CO}_{2}$ formed during reduction in $\mathrm{CO}(0.35 \mathrm{O} / \mathrm{Cu})$; thus, not all $\left\{\mathrm{Cu}^{2+}-\mathrm{O}^{2-}-\mathrm{Cu}^{2+}\right\}^{2+}$ dimers autoreduce, even at $\sim 1100 \mathrm{~K}$. The fraction of the $\mathrm{Cu}$-dimers that desorbs $\mathrm{O}$-atoms as $\mathrm{O}_{2}$ increased with increasing $\mathrm{Cu} / \mathrm{Al}$ ratio (from $35 \%$ in $\mathrm{Cu}(0.12)$ to $57 \%$ in $\mathrm{Cu}(0.58)$; Table 6$)$. As $\mathrm{Cu}$ dimers become more distant with decreasing $\mathrm{Cu} / \mathrm{Al}$ ratio, the probability of recombination decreases. Isolated $\mathrm{Cu}$ dimers do not appear to be able to reduce at all without a reductant capable of removing oxygen as $\mathrm{H}_{2} \mathrm{O}$ or $\mathrm{CO}_{2}$ (or as $\mathrm{NO}_{2}$ during catalytic $\mathrm{NO}$ decomposition).

Two $\mathrm{O}_{2}$ desorption peaks are clearly visible on $\mathrm{Cu}(0.12)$, suggesting that two autoreduction mechanisms or two types of $\mathrm{Cu}$ dimers are responsible for the evolution of $\mathrm{O}_{2}$. At higher $\mathrm{Cu} / \mathrm{Al}$ ratios, two peaks also seem to account for all $\mathrm{O}_{2}$ evolution features (Fig. 10). $\mathrm{O}_{2}$ evolution requires kinetic paths involving either vicinal oxygen atoms or the migration of oxygen atoms located beyond atomic distances. Thus, it seems plausible that the evolution of $\mathrm{O}_{2}$ at low temperatures arises from vicinal $\mathrm{Cu}$ dimers, which can form $\mathrm{O}-\mathrm{O}$ bonds without requiring diffusion. At higher temperatures, more distant dimers can communicate via migration of $\mathrm{Cu}$ dimers and their bridging oxygen, or at high temperatures, even via the formation and diffusion of oxygen radicals. Some, but not all of the $\mathrm{Cu}$ dimers, are able to autoreduce via these latter pathways as part of the high-temperature reduction processes observed in all samples (Fig. 10).

In order to probe these desorption pathways and to detect the migration of any $\mathrm{Cu}$ dimers, which would place them in temporary proximity to each other and lead to $\mathrm{O}_{2}$ formation, we conducted three consecutive $\mathrm{O}_{2}$ desorption experiments on $\mathrm{Cu}(0.60)$ with intervening $\mathrm{O}_{2}$ treatment at $773 \mathrm{~K}$ between them (Fig. 11). Only the high-temperature desorption peak shifted (to lower temperatures) after each desorption cycle (up to $1100 \mathrm{~K}$ ), without any detectable change in the amount of oxygen desorbed $\left(\mathrm{O}_{2} / \mathrm{Cu}=0.10\right)$. Thus, it appears that some migration of the $\mathrm{Cu}$ dimers occurs irreversibly and that this migration tends to decrease the average distance among the $\mathrm{Cu}$ dimers responsible for the high temperature desorption peak. The $\mathrm{Cu}$ dimers appear to retain their newly acquired proximity and to require lower temperatures for oxygen recombination during subsequent desorption cycles. A large fraction of the $\mathrm{Cu}$ dimers, however, is unable to undergo autoreduction even at the highest temperatures of our experiments. Such sites would also be unable to participate in redox cycles requiring recombinative desorption steps. Our recent results $^{22,23}$ have shown, however, that oxygen removal steps involving $\mathrm{NO}_{2}$ formation and decomposition of $\mathrm{NO}_{2}$ and the use of $\mathrm{NO}$ as an oxygen carrier among distant redox sites allow all dimers to participate in NO decomposition redox cycles, irrespective of their relative proximity. 


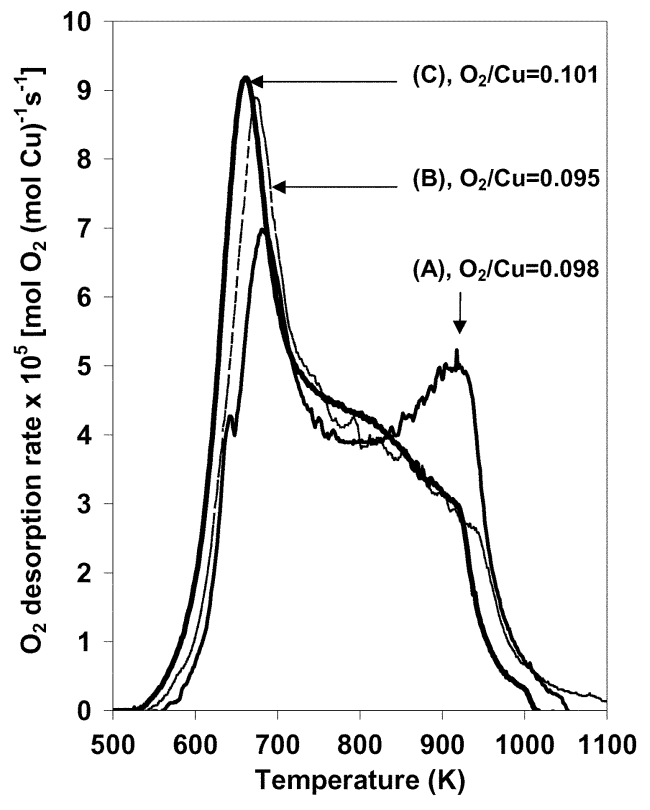

Fig. 11 Oxygen programmed desorption in $\mathrm{He}$ as a function of temperature for $\mathrm{Cu}(0.60)$, (A) first $\mathrm{O}_{2}$-TPD after $\mathrm{O}_{2}$ treatment at $773 \mathrm{~K}$, (B) second $\mathrm{O}_{2}$-TPD after the first one and a new $\mathrm{O}_{2}$ treatment at $773 \mathrm{~K},(\mathrm{C})$ third $\mathrm{O}_{2}$-TPD after the second one and a new $\mathrm{O}_{2}$ treatment at $773 \mathrm{~K}$.

\section{Dependence of catalytic NO decomposition rates on the number of $\mathrm{Cu}$ dimers and monomers}

The mechanism of $\mathrm{NO}$ decomposition on $\mathrm{Cu}-\mathrm{ZSM} 5$, which involves $\mathrm{N}_{2} \mathrm{O}$ and $\mathrm{NO}_{2}$ as intermediates for $\mathrm{N}_{2}$ and $\mathrm{O}_{2}$ formation, respectively, is discussed in detail elsewhere. ${ }^{22,23}$ In this study, the NO decomposition rate data are correlated with the amounts of different $\mathrm{Cu}$ species in order to determine which $\mathrm{Cu}$ species are active for $\mathrm{NO}$ decomposition. Steadystate $\mathrm{NO}$ decomposition rates $\left(\mathrm{N}_{2}+\mathrm{N}_{2} \mathrm{O}\right.$ formed per total $\mathrm{Cu}$ atom) are shown in Fig. 12 for all $\mathrm{Cu}-\mathrm{ZSM} 5$ samples. Except on $\mathrm{Cu}(0.12)$, which gives lower rates and a monotonic increase in rate with increasing temperature, the temperature dependence of catalytic NO decomposition rates shows the usual patterns previously reported on $\mathrm{Cu}-\mathrm{ZSM} 5$. $^{7,47} \mathrm{NO}$ decomposition rates increase with temperature up to $773 \mathrm{~K}$ and then decrease at higher temperature. This behavior reflects a complex interplay between bimolecular surface decomposition steps with low activation energies and the unfavorable thermodynamics for $\mathrm{NO}$ adsorption on $\mathrm{Cu}^{+}$sites at high temperatures. $^{22}$ This rate decrease becomes detectable as $\mathrm{Cu}$ dimers become increasingly reduced at high temperatures.

In order to compare the rates for the various catalysts at the same gas phase composition, the rates were extrapolated to the inlet conditions ( $\left.1 \mathrm{kPa} \mathrm{NO}, 0 \mathrm{kPa} \mathrm{O}_{2}\right)$ using the kinetic rate expression:

$$
r=\frac{k_{\mathrm{app}}[\mathrm{NO}]^{2}}{1+K_{\alpha}\left[\mathrm{O}_{2}\right]^{1 / 2}}
$$

and previously measured values of $K_{\alpha} \cdot{ }^{22} K_{\alpha}$ is the equilibrium constant for dissociative $\mathrm{O}_{2}$ adsorption; it has a value of 3.2 $\mathrm{kPa}^{-1 / 2}$ at $773 \mathrm{~K}$ on $\mathrm{Cu}(0.58) .{ }^{22}$ Three other catalysts, $\mathrm{Cu}(0.36), \mathrm{Cu}(0.38)$ and $\mathrm{Cu}(0.60)$, gave very similar rate expressions and temperature dependences as $\mathrm{Cu}(0.58)$ and we expect similar values of $K_{\alpha}$. On $\mathrm{Cu}(0.12)$, however, the different temperature dependence (Fig. 12) indicates that $K_{\alpha}$ values are much higher than for the other samples, leading to the prevalence of oxidized $\mathrm{Cu}$ dimers even at temperatures above $800 \mathrm{~K}$.

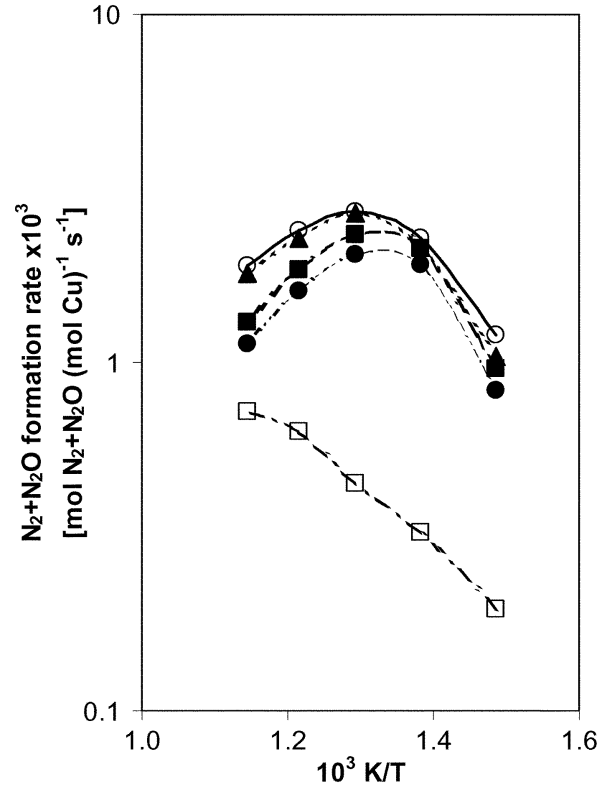

Fig. 12 Arrhenius plot of $\mathrm{N}_{2}+\mathrm{N}_{2} \mathrm{O}$ formation rates on samples with various $\mathrm{Cu} / \mathrm{Al}$ ratios, $(\square \mathrm{Cu}(0.12), \square \mathrm{Cu}(0.38), \bigcirc \mathrm{Cu}(0.58) \bullet \mathrm{Cu}(0.36)$, $\boldsymbol{\Delta} \mathrm{Cu}(0.60)$ ) during NO decomposition at $673-873 \mathrm{~K}$ and $1 \mathrm{kPa}$ NO.

Catalytic NO decomposition rates per $\mathrm{Cu}$ atom increased with increasing $\mathrm{Cu} / \mathrm{Al}$ ratio (Table 7), implicating $\mathrm{Cu}$ dimers, the fraction of which increases with increasing $\mathrm{Cu} / \mathrm{Al}$ ratio, as the active species in NO decomposition turnovers. Turnover rates (per $\mathrm{Cu}^{2+}$ or $\mathrm{Cu}_{\text {dimer }}$ ) calculated from the measured $\mathrm{Cu}$ speciation are also shown in Table 7. NO decomposition turnover rates based on the numbers of $\mathrm{Cu}$ dimers on $\mathrm{Cu}(0.58)$, $\mathrm{Cu}(0.60), \mathrm{Cu}(0.38)$, and $\mathrm{Cu}(0.36)$ are very similar. In contrast, the apparent turnover rate based on $\mathrm{Cu}^{2+}$ monomers increases drastically with increasing $\mathrm{Cu} / \mathrm{Al}$ ratio (Table 7), suggesting that such sites are not involved in NO decomposition turnovers.

The sample with the lowest $\mathrm{Cu} / \mathrm{Al}$ ratio $(\mathrm{Cu}(0.12))$, however, gives much lower turnover rates (per $\mathrm{Cu}$ dimer) than the other catalysts. This reflects the higher $K_{\alpha}$ value for this catalyst, which indicates that bridging oxygen atoms in the $\mathrm{Cu}$ dimers present on this catalyst are more stable and difficult to remove than in the other samples. As a result, redox cycles requiring the removal of these oxygen species are slower and the availability of reduced dimers for NO chemisorption much lower. It appears that the $\mathrm{Cu}$ dimers initially formed at low $\mathrm{Cu}$ contents prefer $\mathrm{Al}-\mathrm{Al}$ pairs leading to very stable oxidized $\mathrm{Cu}$ dimers. This is consistent with the higher temperatures for the first $\mathrm{O}_{2}$ desorption peak and first $\mathrm{CO}_{2}$ formation peak on $\mathrm{Cu}(0.12)$ relative to the other samples. At higher $\mathrm{Cu}$ contents, dimers form less stable structures with weaker $\mathrm{Cu}-\mathrm{O}$ bonds and lower enthalpies for oxygen adsorption, which lead to a higher steady-state density of reduced $\mathrm{Cu}$ species and to faster redox cycles. The difference in reducibility among $\mathrm{Cu}$ dimers of varying stability becomes less important at higher temperature, because reduced sites become the most-abundant surface species during reaction. At these higher temperatures, NO decomposition rates on $\mathrm{Cu}(0.12)$ approach those measured on the other samples (Fig. 12).

These data provide confirming evidence for the involvement of $\mathrm{Cu}$ dimers and of redox cycles in NO decomposition turnovers. ${ }^{22,23}$ The removable oxygen atoms present in $\left\{\mathrm{Cu}^{2+}\right.$ $\left.\mathrm{O}^{2-}-\mathrm{Cu}^{2+}\right\}^{2+}$, but not in isolated $\mathrm{Cu}^{2+}$, are required for rapid redox cycles during NO decomposition. Some reactivity differences among prevalent dimers structures are clearly observed, indicating the presence of $\left\{\mathrm{Cu}^{2+}-\mathrm{O}^{2-}-\mathrm{Cu}^{2+}\right\}^{2+}$ with a range of stability and oxygen binding energy. 
Table 7 Correlation between the $\mathrm{N}_{2}+\mathrm{N}_{2} \mathrm{O}$ formation rates during the NO decomposition at $773 \mathrm{~K}$ ( $1 \mathrm{kPa}$ NO) and the copper species on different $\mathrm{Cu}-\mathrm{ZSM} 5$ catalysts

\begin{tabular}{|c|c|c|c|}
\hline Catalyst & $\begin{array}{l}\mathrm{N}_{2}+\mathrm{N}_{2} \mathrm{O} \text { rate } \times 10^{3} \text { per } \mathrm{Cu} \\
\left(\mathrm{mol}(\mathrm{mol} \mathrm{Cu})^{-1} \mathrm{~s}^{-1}\right)\end{array}$ & $\begin{array}{l}\mathrm{N}_{2}+\mathrm{N}_{2} \mathrm{O} \text { rate } \times 10^{3} \text { per } \\
\mathrm{Cu}_{\text {dimer }}\left(\mathrm{mol}\left(\mathrm{mol} \mathrm{Cu} \mathrm{Cu}_{\text {dimer }}\right)^{-1} \mathrm{~s}^{-1}\right)\end{array}$ & $\begin{array}{l}\mathrm{N}_{2}+\mathrm{N}_{2} \mathrm{O} \text { rate } \times 10^{3} \text { per isolated } \\
\mathrm{Cu}^{2+}\left(\mathrm{mol}\left(\mathrm{mol} \mathrm{Cu}_{\mathrm{i}}\right)^{-1} \mathrm{~s}^{-1}\right)\end{array}$ \\
\hline $\mathrm{Cu}(0.12)$ & 0.56 & 1.23 & 1.05 \\
\hline $\mathrm{Cu}(0.36)$ & 3.98 & 7.10 & 9.05 \\
\hline $\mathrm{Cu}(0.38)$ & 4.71 & 7.84 & 11.80 \\
\hline $\mathrm{Cu}(0.58)$ & 6.42 & 9.18 & 21.40 \\
\hline $\mathrm{Cu}(0.60)$ & 6.64 & 8.52 & 30.20 \\
\hline
\end{tabular}

\section{Conclusions}

$\mathrm{H}_{2}$-TPR monitored by mass spectrometry and in situ X-ray absorption spectroscopy showed that the $\mathrm{Cu}$ on $\mathrm{Cu}-\mathrm{ZSM} 5$ occurs predominantly as isolated exchanged $\mathrm{Cu}^{2+}$ and as exchanged $\mathrm{Cu}$ dimers, $\left\{\mathrm{Cu}^{2+}-\mathrm{O}^{2-}-\mathrm{Cu}^{2+}\right\}^{2+}$ after calcination. These experiments did not detect bulk copper oxide $(\mathrm{CuO})$, as also expected from the low $\mathrm{pH}$ in solution during synthesis and the limited extent to which it was possible to introduce $\mathrm{Cu}$ into the ZSM5 samples. Based on the amount of $\mathrm{CO}_{2}$ that formed during CO-TPR, the fraction of the total $\mathrm{Cu}$ that appears in $\mathrm{Cu}$ dimers increased from 0.46 to 0.78 as $\mathrm{Cu} / \mathrm{Al}$ ratios increased from 0.12 to 0.60 . The $\mathrm{Cu}_{\text {dimer }} / \mathrm{Al}$ ratio increased from 0.06 to 0.47 , whereas the $\mathrm{Cu}^{2+} / \mathrm{Al}$ ratio leveled off at $\sim 0.15$, suggesting that only a fraction of the Al-sites are sufficiently close to another Al-site for them to bind a $\mathrm{Cu}^{2+}$. At higher $\mathrm{Cu} / \mathrm{Al}$ ratios the average $\mathrm{Cu}-\mathrm{Cu}$ distance decreases, and this allows a larger fraction of the $\mathrm{Cu}$ to form $\mathrm{Cu}-\mathrm{O}-\mathrm{Cu}$ bridges as observed from the increase in $\mathrm{Cu}$ dimers with increasing $\mathrm{Cu} / \mathrm{Al}$ ratio. The $\mathrm{Cu}_{\text {dimer }} / \mathrm{Al}$ and $\mathrm{Cu}^{2+} / \mathrm{Al}$ ratios obtained from the amount of $\mathrm{CO}_{2}$ formed in the CO-TPR are consistent with the amount of $\mathrm{H}_{2} \mathrm{O}$ formed during $\mathrm{H}_{2-}$ TPR, and the amount of CO adsorbed after CO-TPR, and also with previously reported theoretical $\mathrm{Al}-\mathrm{Al}$ distribution calculations.

The number of oxygen atoms removed as $\mathrm{O}_{2}$ was significant smaller than that removed with $\mathrm{H}_{2}$ or $\mathrm{CO}$ suggesting that only proximate $\mathrm{Cu}$ dimers autoreduce via recombinative desorption steps during $\mathrm{O}_{2}$-TPD experiments. The fraction of the adsorbed oxygen atoms that can desorb from $\mathrm{Cu}$ dimers increased from 0.35 to 0.57 with increasing $\mathrm{Cu} / \mathrm{Al}$ ratio, showing that a significant fraction of the $\mathrm{Cu}$ dimers remain isolated even at high $\mathrm{Cu} / \mathrm{Al}$ ratios. Multiple peaks appear in both the $\mathrm{O}_{2}$-TPD and the CO-TPR profiles indicating that $\mathrm{Cu}$ dimers exist in various geometries with different stability and reactivity towards $\mathrm{O}_{2}$ and $\mathrm{CO}_{2}$ formation.

The NO decomposition rate per $\mathrm{Cu}$ was found to increase with increasing $\mathrm{Cu} / \mathrm{Al}$ ratio. This increase in rate occurred in parallel with increasing $\mathrm{Cu}_{\text {dimer }} / \mathrm{Al}$ ratios and this correlation suggests that $\mathrm{Cu}$ dimers are the active sites for NO decomposition on $\mathrm{Cu}$-ZSM5. The lower NO decomposition turnover rates (per $\mathrm{Cu}$ dimer) measured on the $\mathrm{Cu}$-ZSM5 with lowest $\mathrm{Cu}$ content appears to reflect the higher oxygen stability on the $\mathrm{Cu}$ dimers first formed during ion exchange, as evidenced by the higher temperature required to form $\mathrm{O}_{2}$ during $\mathrm{O}_{2}$-TPD and $\mathrm{CO}_{2}$ during $\mathrm{CO}$-TPR experiments. Thus, the equilibrium between oxidized and reduced $\mathrm{Cu}$ dimers during NO decomposition is shifted towards oxidized $\mathrm{Cu}$ dimers; as a result, $\mathrm{NO}$ decomposition rates do not decrease as the temperature increases above $773 \mathrm{~K}$, in contrast with the behavior observed on samples with higher $\mathrm{Cu} / \mathrm{Al}$ ratio.

During synthesis, isolated $\mathrm{Cu}^{2+}$ and stable $\mathrm{Cu}$ dimers form initially at lower $\mathrm{Cu} / \mathrm{Al}$ ratios, whereas unstable $\mathrm{Cu}$ dimers form when more $\mathrm{Cu}$ is exchanged into the catalyst. These unstable $\mathrm{Cu}$ dimers are responsible for the higher NO decomposition activity observed at higher $\mathrm{Cu} / \mathrm{Al}$ ratios.

\section{Acknowledgements}

Patrick Da Costa acknowledges the financial support from the French Foreign Affairs Ministry in the form of a "Programme Lavoisier" Grant. The financial support for Björn Modén in the form of a grant from CF Miljöfonden and of Deuk Ki Lee from the Korea Science and Engineering Foundation (KOSEF) are also gratefully acknowledged. Portions of this research were carried out at the Stanford Synchrotron Radiation Laboratory, a national user facility operated by Stanford University on behalf of the U.S. Department of Energy, Office of Basic Energy Sciences.

\section{References}

1 M. Iwamoto, S. Yokoo, K. Sakai and S. Kawaga, J. Chem. Soc., Faraday Trans., 1981, 177, 1629.

2 M. Shelef, K. Otto and H. Gandhi, Atmos. Environ., 1969, 3, 107.

3 A. Amirnazmi and M. Boudart, J. Catal., 1975, 39, 383.

4 M. Iwamoto, H. Yahiro, W. Mizuno, W.-X. Zhang, Y. Mine, H. Furukawa and S. Kagawa, J. Phys. Chem., 1992, 96, 9360.

5 S. C. Larsen, A. W. Aylor, A. T. Bell and J. A. Reimer, J. Phys. Chem., 1994, 98, 11533.

6 E. Giamello, D. Murphy, G. Magnacca, C. Morterra, Y. Shioya, T. Nomura and M. Anpo, J. Catal., 1992, 136, 510.

7 Y. Li and W. K. Hall, J. Catal., 1991, 129, 202.

8 H.-J. Jang, W. K. Hall and J. L. d'Itri, J. Phys. Chem., 1996, 100, 9416.

9 W. Grunert, N. W. Hayes, R. W. Joyner, E. S. Shpiro, M. R. H. Siddiqui and G. N. Baeva, J. Phys. Chem., 1994, 98, 10832.

10 D.-J. Liu and H. J. Robota, Catal. Lett., 1993, 21, 291.

11 D.-J. Liu and H. J. Robota, Appl. Catal., B, 1993, 4, 155.

12 M. Shelef, Catal. Lett., 1992, 15, 305.

13 A. W. Aylor, S. C. Larsen, J. A. Reimer and A. T. Bell, J. Catal., 1995, 157, 592.

14 G. Spoto, A. Zecchina, S. Bordiga, G. Ricchiardi and G. Martra, Appl. Catal., B, 1994, 3, 151.

15 W. K. Hall and J. Valyon, Catal. Lett., 1992, 15, 311.

16 J. Valyon and W. K. Hall, J. Phys. Chem., 1993, 97, 1204.

17 J. Valyon and W. K. Hall, J. Catal., 1993, 143, 520.

18 J. Sarkany, J. L. d'Itri and W. M. H. Sachtler, Catal. Lett., 1992, 16, 241.

19 G. D. Lei, B. J. Adelman, J. Sarkany and W. M. H. Sachtler, Appl. Catal., B., 1995, 5, 245.

20 T. Beutel, J. Sarkany, G. D. Lei, J. Y. Yan and W. M. H. Sachtler, J. Phys. Chem., 1996, 100, 845.

21 G. Moretti, Catal. Lett., 1994, 23, 135.

22 B. Moden, P. Da Costa, B. Fonfe, D. K. Lee and E. Iglesia, J. Catal., 2002, 209, 75.

23 B. Moden, P. Da Costa, D. K. Lee and E. Iglesia, J. Phys. Chem $B, 2002$, in press.

24 G. D. Meitzner and E. Iglesia, Catal. Today, 1999, 53, 433.

25 D. G. Barton, S. L. Soled, G. D. Meitzner, G. A. Fuentes and E. Iglesia, J. Catal., 1999, 181, 57.

26 T. Ressler, http://ourworld.compuserve.com/homepages/ t_ressler/.

27 (a) T. Ressler, J. Phys. IV, 1997, 7, C2; (b) T. Ressler, J. Synchrotron Radiat., 1998, 5, 118.

28 E. R. Malinowski and D. G. Howery in Factor Analysis in Chemistry, Wiley, New York, 1981.

29 G. D. Meitzner and E. S. Huang, Fresenius' J. Anal. Chem., 1992, 342, 61 .

30 J. Dedecek and B. Wichterlova, J. Phys. Chem. B, 1997, 101, 10233. 
31 Y. Zhang, K. M. Lee, A. F. Sarofim, Z. Hu and M. Flytzani-Stephanopoulos, Catal. Lett., 1995, 31, 75.

32 M. Iwamoto, H. Yahiro, K. Tanda, N. Mizuno and Y. Mine, J. Phys. Chem., 1991, 95, 3727.

33 A. V. Kucherov, A. A. Slinkin, D. A. Kondratev, T. N. Bondarenko, A. M. Rubinstein and K. M. Minachev, Zeolites, 1985, 5, 320 .

34 C. Lamberti, S. Bordiga, M. Salvalaggio, G. Spoto, A. Zecchina, F. Geobaldo, G. Vlaic and M. Bellatreccia, J. Phys. Chem. B., 1997, 101, 344.

35 K. C. C. Kharas, D.-J. Liu and H. J. Robota, Catal. Today, 1995, 26, 129.

36 J. M. Tranquada, S. M. Heald and A. R. Moodenbaugh, Phys. Rev. B, 1987, 36, 5263 .

37 J. M. Brown, L. Powers, B. Kincaid, J. A. Larrabee and T. G. Shirp, J. Am. Chem. Soc., 1980, 102, 4210.

38 L. S. Kau, D. J. Spira-Salomon, J. E. Penner-Hahn, K. O Hodgson and E. I. Salomon, J. Am. Chem. Soc., 1987, 109, 6433 .
39 Y. Kuroda, Y. Yoshikawa, S. Konno, H. Hamano, H. Maeda, R. Kamashiro and M. Nagao, J. Phys. Chem., 1995, 99, 10621.

40 J. Sarkany and W. M. H. Sachtler, Zeolites, 1994, 14, 7.

41 M. J. Rice, A. K. Chakraborty and A. T. Bell, J. Catal., 1999, 186 , 222.

42 M. J. Rice, A. K. Chakraborty and A. T. Bell, J. Catal., 2000, 194 278.

43 M. J. Rice, A. K. Chakraborty and A. T. Bell, J. Phys. Chem. B, 2000, 104, 9987.

44 E. Eranen, N. Kumar and L.-E. Lindfors, Appl. Catal. B., 1994, 4, 213.

45 Y. Teraoka, C. Tai, H. Ogawa, H. Furukawa and S. Kagawa, Appl. Catal. A, 2000, 200, 167.

46 Z. Wang, A. V. Sklyarov and G. W. Keulks, Catal. Today, 1997, 33, 291.

47 M. Iwamoto, H. Furukawa, Y. Mine, F. Uemura, S. Mikuriya and S. Kagawa, J. Chem. Soc., Chem. Commun., 1986, 1272. 